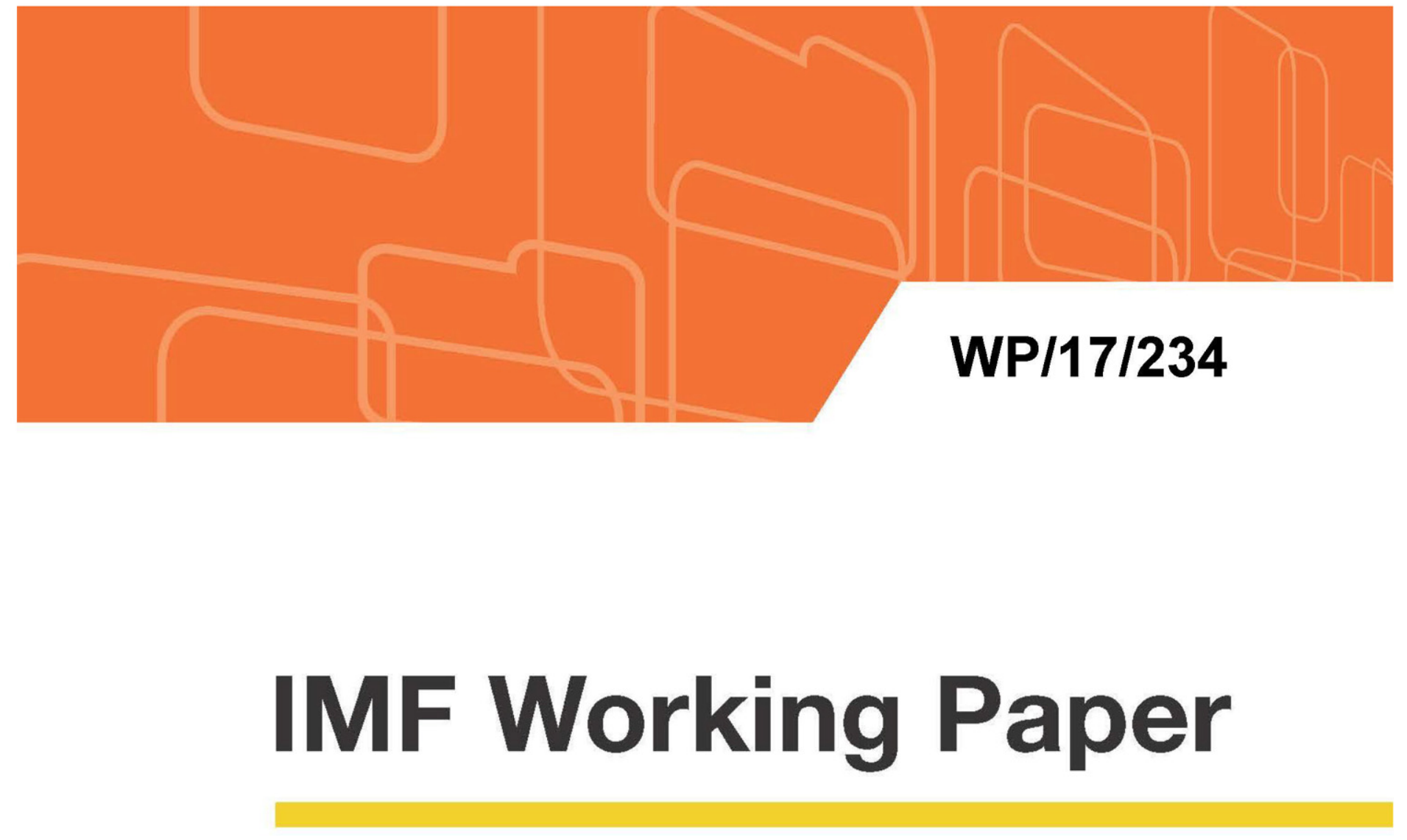

\title{
Bank Lending in the Knowledge Economy
}

by Giovanni Dell'Ariccia, Dalida Kadyrzhanova, Camelia Minoiu, and Lev Ratnovski

IMF Working Papers describe research in progress by the author(s) and are published to elicit comments and to encourage debate. The views expressed in IMF Working Papers are those of the author(s) and do not necessarily represent the views of the IMF, its Executive Board, or IMF management. 


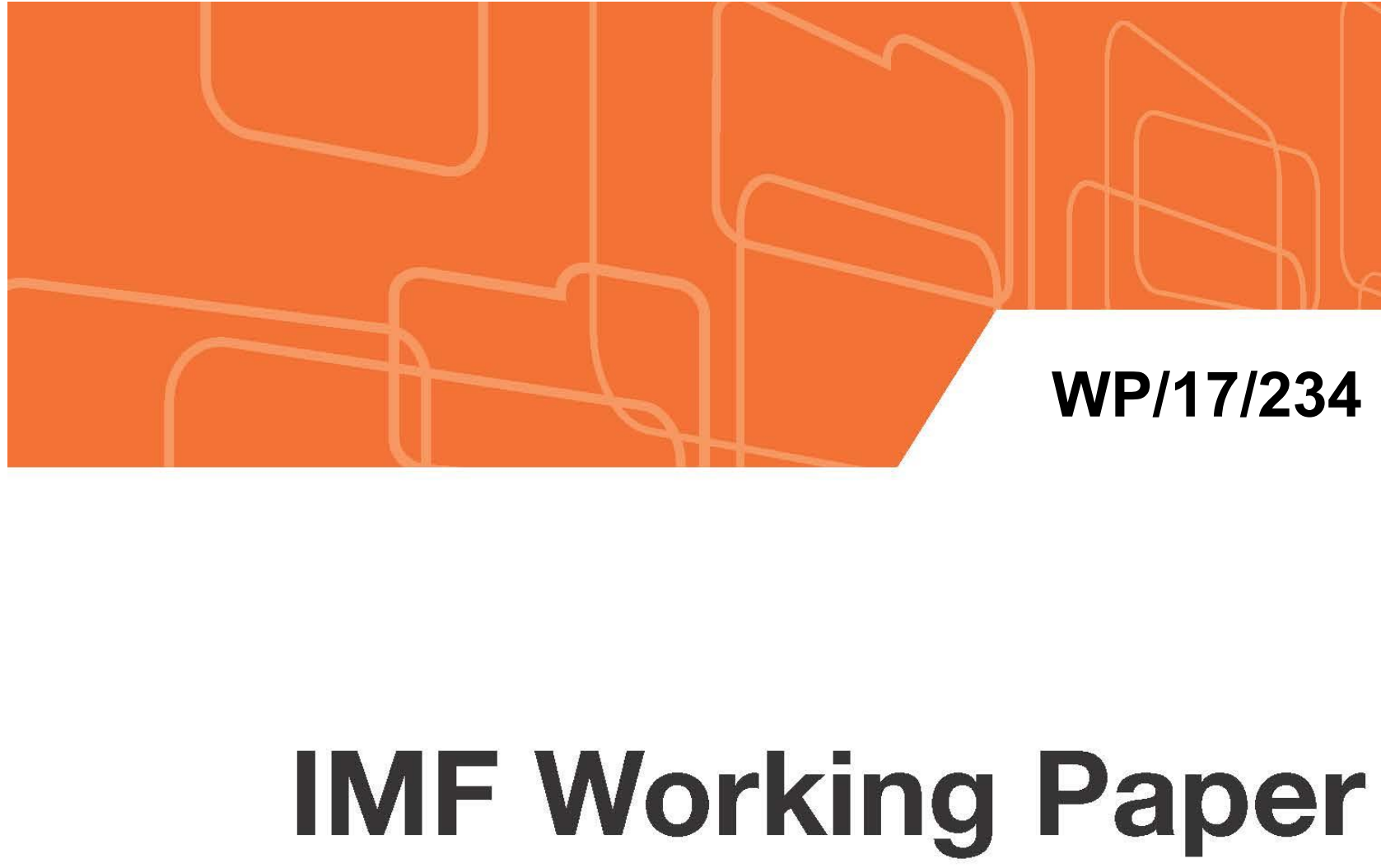

\section{Bank Lending in the Knowledge Economy}

by Giovanni Dell'Ariccia, Dalida Kadyrzhanova, Camelia Minoiu, and Lev Ratnovski

IMF Working Papers describe research in progress by the author(s) and are published to elicit comments and to encourage debate. The views expressed in IMF Working Papers are those of the author(s) and do not necessarily represent the views of the IMF, its Executive Board, or IMF management. 


\title{
IMF Working Paper
}

Research Department

Bank Lending in the Knowledge Economy
Prepared by Giovanni Dell'Ariccia, Dalida Kadyrzhanova, Camelia Minoiu, and Lev Ratnovski ${ }^{1}$

November 2017

\begin{abstract}
IMF Working Papers describe research in progress by the author(s) and are published to elicit comments and to encourage debate. The views expressed in IMF Working Papers are those of the author(s) and do not necessarily represent the views of the IMF, its Executive Board, or IMF management.
\end{abstract}

\begin{abstract}
We study bank portfolio allocations during the transition of the real sector to a knowledge economy in which firms use less tangible capital and invest more in intangible assets. We show that, as firms shift toward intangible assets that have lower collateral values, banks reallocate their portfolios away from commercial loans toward other assets, primarily residential real estate loans and liquid assets. This effect is more pronounced for large and less well capitalized banks and is robust to controlling for real estate loan demand. Our results suggest that increased firm investment in intangible assets can explain up to $20 \%$ of bank portfolio reallocation from commercial to residential lending over the last four decades.
\end{abstract}

JEL Classification Numbers: E22, E44, G21, G28

Keywords: intangible capital, bank lending, commercial loans, real estate loans, liquid assets Author's E-Mail Address: gdellariccia@imf.org; dkadyrzhanova@gsu.edu; cminoiu@imf.org; lratnovski@imf.org

\footnotetext{
${ }^{1}$ We thank Jean-Edouard Colliard, Sapnoti Eswar, Linda Goldberg, Itay Goldstein, Jessie Handbury, Ann Harrison, Lixin Huang, Divya Kirti, Tomasz Michalski, Chip Ryan, Sascha Steffen, Xiaoyun Yu, Kathy Yuan, seminar participants at University of New South Wales, University of Delaware, Fordham, Villanova, Georgia State, the ECB, the IMF, and conference participants at the AEA 2017, 10th Swiss Winter Conference on Financial Intermediation (Lenzerheide), Adam Smith Workshops in Corporate Finance (HEC Paris), Chicago Financial Institutions Conference, NBER Summer Institute 2017, FIRS 2017, and EFA 2017 for helpful comments. We thank Jae Chung and Huy Nguyen for excellent research assistance. The views expressed in this paper are those of the authors, and should not be attributed to the IMF, its Executive Board, or its management.
} 


\section{Table of Contents}

1. Introduction

2. Literature review and hypothesis construction

3. Data and empirical strategy

4.1 Firm and MSA-level measures of intangible capital

4.2 Bank- and MSA-level data

4.3 Empirical specifications

4. Results

5.1 Corporate intangible capital and bank asset allocations

5.2 Bank size and capital $\quad \underline{14}$

5. Adressing potential omitted variable problems $\quad \underline{16}$

6.1 Control for unobserved macro factors $\quad \underline{17}$

6.2 Exploit correlation of intangible assets and macro variables $\quad \underline{18}$

6.3 Effects on bank profitability $\quad \underline{19}$

6. Robustness tests $\quad \underline{20}$

7.1 The effects of bank branching deregulation $\quad \underline{20}$

7.2 Alternative specifications and further refinements $\underline{\underline{21}}$

7. Conclusions $\quad \underline{22}$

References

Appendix $\quad \underline{40}$

\section{List of figures}

1. Corporate intangible assets and bank C\&I loans, 1977-2010 $\underline{26}$

2. Corporate intangible assets, and bank loan portfolios, 1977-2010 $\underline{27}$

3. Growth rate of corporate intangible assets, 1977-2010 $\underline{28}$

4. Correlations of corporate intangible assets and macro variables, 1977-2010 $\underline{29}$

\section{List of tables}

1. Descriptive statistics $\underline{30}$

2. Corporate intangible capital and bank portfolio allocations-Baseline $\quad \underline{31}$

3. Corporate intangible capital and the components of non-C\&I loans $\underline{32}$

4. Corporate intangible capital and bank portfolio allocations-High vs. low changes in $\underline{33}$ intangible capital

5. Corporate intangible capital and bank portfolio allocations - Heterogeneity by bank size and $\underline{34}$ capital (bank and year fixed effects)

6. Corporate intangible capital and bank portfolio allocations - Heterogeneity by bank size and $\underline{35}$ capital (bank and MSA*year fixed effects)

7. Corporate intangible capital and bank portfolio allocations-Ruling loan demand out as a $\underline{36}$ possible channel (1)

8. Corporate intangible capital and bank portfolio allocations - Ruling loan demand out as a $\underline{37}$ possible channel (2)

9. Corporate intangible capital and bank profitability $\quad \underline{38}$

10. Corporate intangible capital and bank portfolio allocations-Identification using interstate $\underline{39}$ bank branching deregulation 


\section{Introduction}

Over the past few decades, the importance of intangible capital in corporate balance sheets has steadily increased. Intangible assets tend to be more firm-specific and more difficult to verify, price, and liquidate than tangible assets. As such, they offer less collateral value. Thus, the rise in intangible capital may lead to an increase in intermediation frictions. Borrowers whose technology entails a large share of intangible assets may find it difficult to obtain funding through secured lending. This phenomenon is convincingly documented by a growing literature that links the rise in intangible capital to lower corporate debt capacity and greater reliance on internal financing (e.g., Bates et al. (2009), Falato et al. (2013)). However, how this friction affects the banking sector remains unexplored.

In this paper, we hypothesize that the economy-wide rise in intangible capital has contributed to a secular decline in the share of banks' portfolios allocated to commercial lending. If intangible capital significantly reduces firms' debt capacity, it is plausible that commercial and industrial (C\&I) loans decline as firms are less able to rely on bank loans (and debt more generally) to finance their investment opportunities. Reduced commercial lending opportunities arising from this friction may in turn induce banks to reallocate their lending capacity to non-C\&I assets, such as real estate loans and liquid assets.

At the aggregate level, the negative correlation between corporate intangible assets and the share of commercial loans in bank portfolios is self-evident (Figure 1). For U.S. corporates, the share of intangible assets relative to firms' tangible assets rose from roughly $40 \%$ in the 1970 s to over $100 \%$ in the 2000s. Over the same period, the share of commercial loans in banks' total assets fell by a third, while the share of real estate loans almost doubled (Figure 2).

To establish a causal link between these trends, we exploit geographical variation in corporate intangible capital and bank portfolio allocations. Our empirical tests examine how banks' commercial loans and total assets respond to the growth in intangible capital for firms located in the same Metropolitan Statistical Area (MSA) as the bank, in a large bank-level panel over 1977-2010. We also examine banks' non-C\&I asset allocations, with a focus on the growth rates of real estate loans and liquid assets. If intangible assets imply fewer opportunities for commercial lending, then the decline in commercial loan growth should be more pronounced for banks operating in markets where the increase in intangible assets is larger. We use firms sharing the same MSA location as 
banks as a proxy for banks' corporate lending client base. This approach hinges on the assumption that banks cannot easily diversify away intangible asset-related shocks to their commercial lending opportunities by reallocating commercial loan portfolios to other locations. We acknowledge this matching is imperfect. Yet, the measurement error is likely to be smaller in the first half of our sample when banks had limited scope for cross-state activities and could not easily shift operations geographically. Our empirical tests take advantage of these restrictions for a stronger identification.

We find evidence that the rise in corporate intangible capital reduces commercial loan growth, controlling for bank fixed effects, time-varying bank characteristics, and variables that capture MSA-level demand for bank loans. In our main specification, coefficient estimates indicate that a one standard deviation increase in intangible capital is accompanied by a contraction in bank C\&I lending by 2 to 3.5 percentage points. This effect is statistically and economically significant and implies that up to $20 \%$ of the secular decline in the share of commercial loans in total bank lending since the mid-1970s can be attributed to the increase in corporate intangible capital over the same period. In addition, we find that banks that are exposed to a higher growth rate of MSA-level corporate intangible capital do not reduce their size. Instead, bank balance sheets show a higher growth rate of non-C\&I assets, especially residential real estate loans and liquid assets. This result suggests that banks respond to fewer opportunities in corporate lending by reallocating their lending capacity to different types of assets rather than by contracting their balance sheets.

To support a causal interpretation of our results, we present a series of additional results. One potential concern is that intangible corporate capital affects bank lending through channels other than the lower availability of collateral. For example, more intangible-capital intensive firms may systematically attract a different, more skilled and better paid workforce, leading to increased demand for real estate or consumer loans, both of which are part of banks' non-C\&I assets. We address this concern in three ways. First, our baseline specifications control for non-C\&I loan demand with a battery of MSA-level variables such as population growth, per capita household income growth, and house price growth. Second, we confirm that the results hold up in subsamples of MSAs where intangible capital growth is least correlated to several measures of non-C\&I loan demand, as well as in subsamples of MSAs that did not experience a house price boom. Third, in specifications that focus on bank balance-sheet interactions with corporate intangible capital, we add interacted MSA $\times$ year fixed effects to control for all unobserved time-varying macroeconomic factors that can drive housing demand at the MSA level. In all these tests, the estimated coefficients 
of interest remain statistically significant and have virtually unchanged magnitudes, suggesting that the demand for non-C\&I loans does not drive our results.

We also exploit the deregulation of interstate bank branching activities that took place between the late 1970s and early 1990s to compare the asset allocations of banks facing restrictions in their ability to lend out of state ("regulated") with those not facing such restrictions ("deregulated"). The staggered timing of the removal of geographic restrictions on bank expansion allows us to estimate a differences-in-differences specification. For a given increase in local intangible capital, we expect regulated banks, which are less geographically diversified and hence less able to diversify local intangible capital shocks away, to exhibit a greater contraction of commercial lending. The results are consistent with this hypothesis. In addition, the point estimates for regulated banks are sizable and greater than those in the baseline regressions. We view these point estimates as closer to the true magnitude of the pressures on C\&I lending experienced by banks at the aggregate level throughout our sample period since the economy-wide rise in corporate intangible capital cannot easily be diversified away by banks.

This final set of results further helps us rule out that our results are due to unobserved positive shocks to demand for non-C\&I loans. If unobserved non-C\&I loan demand were driving our results, then this effect should be more pronounced for deregulated banks, which would better be able to attract capital from other locations to accommodate the demand shock (see, e.g., Cortés and Strahan (2015)). However, our results show significantly smaller effects for deregulated banks than for regulated banks. This evidence is consistent with our hypothesis that local intangible capital shocks, which reduce the borrowing capacity of firms, in turn lead banks to reallocate their lending to other sectors.

Our findings offer a new perspective on the long-term decline in the share of commercial loans in bank assets by showing that a significant part of this decline was due to the shift to a higher reliance on intangible capital in the corporate sector. Moreover, our evidence suggests that banks responded to this phenomenon by reallocating their portfolios toward other types of assets, in particular real estate loans and liquid assets, rather than downsizing. Thus, our results imply the rise in corporate intangible capital over the last few decades has contributed to the expansion of real estate lending and the downward pressure on interest rates through this bank portfolio reallocation channel.

The long-term shift in bank lending away from C\&I and toward real estate loans has so far been explained on the basis of developments in real estate and housing markets. Standard explanations 
include the rise in house prices and securitization (Loutskina and Strahan (2009) and Chakraborty et al. (2016)) and the development of securities markets. However, over the same time period, a fundamental change has simultaneously taken place in the nature of corporate sector assets. In the last four decades, firms have increasingly invested in intangible capital, including technological innovation and organizational capabilities. Corrado et al. (2005) estimate that the aggregate stock of U.S. corporate intangible capital has grown five-fold since the 1960s, and by the early 2000s it had reached the same magnitude as tangible capital.

Our study is the first to show that developments in the corporate sector may have played an important role as well. While this channel has been articulated theoretically in Caggese and Perez (2016) and Döttling and Perotti (2016), our paper provides the first empirical evidence that the rise of corporate intangible capital is a quantitatively important contributor to the long-run reallocation of bank lending away from commercial loans to real estate loans and liquidity holdings. Thus, even if real estate demand subsides (due to a fall in house prices, for example) and risk appetite in financial markets wanes, our results imply that the supply pressures in real estate lending and the demand by banks for liquid assets, with the resulting downward pressure on interest rates, will likely persist, since they partly emanate from the long-run transformation of the corporate sector.

The remainder of the paper proceeds as follows. Section 2 reviews selected related studies and develops our hypotheses. Section 3 discusses our data and empirical strategy. Section 4 presents the baseline results. Sections 5 and 6 address potential endogeneity concerns and present our robustness checks. Section 7 concludes.

\section{Literature Review and Hypothesis Construction}

Collateral facilitates financial intermediation by limiting the agency problems associated with asymmetric information and the inalienability of human capital (Hart and Moore, 1994). Banks can use collateral to sort applicant borrowers in high and low risk buckets (reducing adverse selection, as in Bester (1985)) and to provide borrowers with the incentives that increase the probability of repayment (reducing moral hazard, as in Chan and Thakor (1987)). Consequently, credit is cheaper and more abundant when collateralizable assets are readily available. This is immediately evident in consumer-credit markets, where households can obtain for mortgages lending terms (both in volumes and interest rates) that are unattainable for other forms of borrowing. Overall, the liter- 
ature suggests that collateral serves to reduce agency-related frictions in commercial lending in a way that cannot be replicated efficiently by other means (such as enhanced borrower screening or monitoring) (Berger and Udell, 1990; Rajan and Winton, 1995).

Importantly, not all assets lend themselves equally to be used as collateral. Some assets (often intangible ones) are more firm-specific and have lower liquidation values than others. For instance, the value of a partially developed piece of software is likely to be intrinsically linked with the human capital of the programmers who work on it. Should a bank take over this asset and try to sell it on the market, it would likely recoup only a fraction of its original value.

A growing literature in corporate finance examines the link between intangible capital and firm financing. Intangible assets are less valuable as collateral and hence increase frictions in debt finance. As a result, firms tend to finance intangible assets primarily through equity or internal cash flow (Carpenter and Petersen (2002); Brown et al. (2009), Bates et al. (2009), Brown et al. (2013). That said, some intangible assets, notably patents, can have some collateral value (Loumioti (2012), Mann (2015)). Furthermore, lenders can acquire expertise in lending to intangible-capital intensive firms (Chava et al., 2013).

It follows that firms whose production functions rely primarily on intangible capital may find it more difficult to provide collateral to secure their borrowing. Then, at the aggregate level, a technological trend that moves production away from processes that are based on physical capital and towards processes that are based on intangible assets may act as a financial-frictions shock. The reduction of collateralizable assets in the hands of entrepreneurs in need of funds reduces lenders' and borrowers' ability to deal with agency problems associated with debt financing.

For the affected firms, increased intermediation frictions are similar to a negative supply credit shock. These borrowers will find it more difficult and/or expensive to obtain credit. In equilibrium, loan volumes will decrease (as collateral constraints become more binding) and/or interest rates will increase (as banks compensate on the price side for the increased riskiness of loans). (In contrast, for borrowers with abundant collateral, the equilibrium result may be akin to a positive supply shock, as banks may reallocate some of their lending capacity towards these markets.) For banks, an increase in intermediation frictions reduces the mass of qualified borrowers and hence to some extent acts as a negative credit demand shock in the affected market segment. Banks will find it more difficult to lend to commercial enterprises and will tend to reallocate their portfolio towards alternative investments such as real-estate based lending and securities. While the corporate finance 
frictions associated with intangible assets have been well studied in the literature, to our knowledge, ours is the first paper to study the effect of frictions associated with intangible productive assets not on the corporate financing of firms, but on the lending constraints and lending dynamics of commercial banks.

Based on this discussion, we formulate our main empirical hypotheses. Think of a bank that allocates its balance sheet capacity between two types of assets: C\&I loans and non-C\&I assets. Bank liabilities are standard. To focus on the core of the argument, the impact of higher frictions in C\&I lending, assume for now that the properties of non-C\&I assets, as well as those of bank liabilities, are invariant.

Empirical hypothesis 1: Higher corporate intangible assets reduce the equilibrium volume of bank C\&I lending, all else equal.

In addition, as discussed, frictions in commercial lending would also affect the broader composition of the bank's balance sheet. First, these frictions make assets other than commercial loans a relatively more attractive investment. Consequently, banks may reallocate their balance sheet capacity to non-C\&I assets. A bank may, for example, increase the supply of real estate loans or its demand for MBS and other securities. Second, these frictions make bank assets on average less profitable (as the attractiveness of C\&I loans declines, and the return on non-C\&I assets remains constant or declines due to the price effects of banks reallocating their balance sheet capacity towards them). Consequently, banks may reduce the size of their balance sheets. The relative importance of the two effects is a priori unclear.

Empirical hypothesis 2: Higher corporate intangible assets increase the equilibrium volume of bank non-C\&I assets, reduce the equilibrium size of bank balance sheets, or lead to a combination of the two.

Empirically testing hypotheses 1 and 2 forms the core of our analysis. The mechanism behind these hypotheses closely follows the emerging theoretical literature on the effects of intangible capital on financial intermediation

We conduct several supplementary tests, which can be viewed as corollaries of the main argument. We test whether more financially-constrained banks - those with lower capital — are more likely to reduce the size of their balance sheet rather than to increase non-C\&I assets in response to higher corporate intangible assets. We also test whether higher intangible assets reduces bank profitability. 


\section{Data and Empirical Strategy}

We are interested in exploring the link between the rise in corporate intangible capital and bank portfolio allocations. The analysis hinges on matching banks and firms based on their headquarters' MSA, and exploring how bank portfolios change in response to changes in corporate intangible capital. For this purpose, we gather data on firms' intangible capital and other characteristics, bank balance sheets, and MSA-level macroeconomic variables. Here we describe our main variables and present descriptive statistics. Summary statistics for our main variables are reported in Table 1. Variable sources and definitions are in Appendix Figure A1.

\subsection{Firm and MSA-level measures of intangible capital}

Unlike physical (tangible) capital such as property, plant, and equipment, intangible capital is more difficult to measure since investments in intangible assets are typically reported as an expense in the year they are incurred and capital that is created by such investments is not captured on firms' balance sheets. Our measure of intangible capital is constructed from past investments in intangible assets, following the approach in Falato et al. (2013).

To construct intangible capital at the firm level, we use accounting data from Compustat between 1977 and 2010. As is standard in the literature, we exclude financial firms (SIC codes 6000-6999) and regulated utilities (SIC codes 4900-4999), as well as firms with missing or non-positive book values of assets or sales in any given year. This selection process results in a final set of 176,877 firm-year observations for 18,535 unique firms. The measure of intangible capital is computed, for each firm-year, as the sum of the capital accumulated through three types of intangible investments whose importance has been emphasized in the literature on the economics of innovation: knowledge capital, organizational capital, and informational capital (Corrado et al., 2009; Corrado and Hulten, 2010).

Knowledge capital is constructed by capitalizing past R\&D expenditures using the perpetual inventory method with depreciation rate of $15 \%$ (Hall et al., 2001). ${ }^{1}$ Organizational capital is constructed by capitalizing past selling, general and administrative (SG\&A) expenses with depreciation rate of 20\% (Lev and Radhakrishnan, 2005; Eisfeldt and Papanikolaou, 2013). Investments

\footnotetext{
${ }^{1}$ For each component, we set the initial stock to be equal to the expenditure in the first year divided by the respective depreciation rate. In addition, for $R \& D$, we interpolate missing values following Hall (1993) who shows that this results in an unbiased measure of $R \& D$ capital. We set $R \& D$ to zero for firms that do not report $R \& D$.
} 
in organizational capabilities represent expenditures on enhancing the value of brand names and other knowledge embedded in firm-specific human and structural resources and include employee training costs, payments to management and strategy consultants, and distribution systems. Since SG\&A expenditures include many expenses that are unrelated to investments in organizational capabilities, we follow Corrado et al. (2005) and weigh the constructed stock of organizational capital by 0.2 . Finally, informational capital is constructed by capitalizing expenditures on computerized information and software with a depreciation rate of $31 \%$ following BEA, using (2-SIC) industry BEA Fixed Reproducible Tangible Wealth data. ${ }^{2}$

As the final step, we normalize the measure of intangible capital by total tangible assets, i.e., total balance sheet assets excluding cash. Our resulting estimate for the average intangible-to-tangible capital ratio at the firm level in mid-2000s is about $120 \%$, which is comparable to the estimate in Corrado et al. (2005) based on aggregate National Income and Product Accounts.

Our empirical approach examines the effect of intangible capital for firms in a given MSA on the asset allocations for banks that are headquartered in the same MSA. For each firm in Compustat, we match the state and county of its headquarters as reported in Compustat to MSA by merging the State/County FIPS code $^{3}$ with the Metropolitan Areas and Components data defined by the Office of Management and Budget as of 2010. ${ }^{4}$ We define the MSA-level intangible capital as the simple (unweighted) average of the intangible capital to total asset ratio of the firms that are headquartered in that MSA.

The average MSA in our sample has 73 firms with an intangible capital ratio (to book assets net of cash) of $67.8 \%$. The average growth rate of the intangible capital ratio is $14 \%$ in the cross-section of MSAs. Among the more populated MSAs (with at least 10 firms), the top 5-Reno-Sparks (NV), Boulder (CO), Riverside-San Bernardino (CA), Denver-Aurora (CO), and Salt Lake City (UT)experienced an average annual intangible capital growth rate of at least $20 \%$ during 1977-2010. In the bottom 5 MSAs - Grand Rapids-Wyoming (MI), Richmond (VA), Louisville-Jefferson (KY), Akron $(\mathrm{OH})$, and Greater Hartford $(\mathrm{CT})$ - corporate intangible capital grew on average at below

\footnotetext{
${ }^{2}$ See Falato et al. (2013) for details.

${ }^{3}$ The State/County combination defines the State/County code according to the Federal Information Processing Standards (FIPS).

${ }^{4}$ One potential issue with the Compustat location data is that Compustat only reports the current state and county of firms' headquarters. Thus, to make reliable inference about firm location, it is important to correct for this deficiency. For this purpose, we use physical Compustat tapes to collect manually the historical information on firms's headquarters on an annual basis over 1990-2010 and backfill this information for 1977-1989 (see Falato et al. (2013)).
} 
$10 \%$.

Figure 3 plots the histogram of growth rates of firms' intangible capital ratio (Panel A), showing that about $10 \%$ of MSA-year observations experience negative growth rates during the sample period. A time series box plot of intangible capital growth (Panel B) reveals a large amount of cross-sectional (cross-MSA) variation in the data, while the entire distribution of intangible capital growth rates remains fairly stable over time.

\subsection{Bank- and MSA-level data}

Bank balance sheet data for individual banks comes from the U.S. Call Reports. We restrict our sample to commercial banks (variable RSSD9331). We use data on non-consolidated accounts that reflect domestic operations and ignore banks' foreign activities. The bank-level panel runs from 1977 until 2010, the same time period over which we have data on both intangible capital and bank balance sheets. For each bank we observe the MSA of its headquarters (variable RSSD9180). The baseline regressions cover about 8,500 commercial banks that are headquartered in 278 MSAs.

The outcomes of interest are banks' commercial loans, real estate loans, liquid assets, and total assets. Commercial loans are defined as (secured or unsecured) loans for commercial and industrial purposes to sole proprietorships, partnerships, corporations, and other business enterprises. This category excludes loans secured by real estate (which are classified as "real estate loans"), agricultural loans, and personal consumer loans. Liquid assets defined as the sum of cash, U.S. Treasury obligations, mortgage-backed securities, and net interbank lending

The main explanatory variable is the growth rate of intangible capital (as a share of total book assets) of firms that are headquartered in the same MSA as the bank. That is, banks and firms are matched on MSA so that the exposure of each bank to MSA-level intangible capital is the average of intangible capital shares of the firms headquartered in that MSA. This matching comes with the caveat that some firms may borrow from banks that are located in other MSAs and some banks may diversify their C\&I lending beyond their headquarters MSA. This might be especially occurring since the mid-1990s as banks have become more geographically diversified due to increased deregulation of bank activities and due to bank consolidation. This imperfect matching introduces measurement error in the specifications, which we address in Section 6.1.

Data on MSA-level macroeconomic variables such as household income and population come 
from the Bureau of Economic Analysis. Household income is available at the county level and is aggregated at the MSA level using a crosswalk between counties and MSAs from the U.S. Census Bureau. MSA-level house prices come from the Federal Housing Finance Agency (FHFA). We use the "all transactions" seasonally-adjusted house price index (HPI).

\subsection{Empirical specifications}

We estimate baseline specifications for four bank balance sheet variables: commercial loan growth, total asset growth, and the growth rates of two main components of non-C\&I assets: real estate loans and liquid assets. Specifically, we estimate:

$$
Y_{i j t}=\alpha_{i}+\gamma_{t}+\beta_{1} I K_{j t}+\beta_{2} X_{j t}+\beta_{3} Z_{i t}+\epsilon_{i j t}
$$

where banks are indexed by $i$, MSAs by $j$ and years by $t . Y_{i j t}$ is each of the four dependent variables considered. $I K_{j t}$ is the MSA-level growth rate of intangible capital (to total assets). $X_{j t}$ is a matrix of MSA-level macroeconomic variables that serve as proxies for local economic conditions and demand for bank credit (e.g., house prices, per capita income, population, and firm sales). $Z_{i t}$ is a matrix of bank-level controls such as bank size (log-total assets) and bank capital (total equity divided by total capital).

All variables except bank capital and size are expressed in year-on-year growth rates. The point estimates on macroeconomic controls thus capture the relationship between changes in local economic conditions and bank balance sheet components growth. In addition, all specifications with components of the balance sheet as outcome variables - commercial loans, real estate loans, and liquid assets - control for total balance sheet growth. Corporate intangible capital is defined as the growth rate of the ratio of intangible assets to tangible (book) assets. Thus, the coefficient estimate on this variable, $\beta_{1}$, captures the change in the external finance friction in banks' lending to firms. All specifications include bank and year fixed effects. In robustness checks we also estimate a specification with MSA $\times$ year fixed effects to control for all unobserved time-varying macroeconomic factors at the MSA level. All baseline specifications use Ordinary Least Squares (OLS), with standard errors clustered at the bank level. ${ }^{5}$

\footnotetext{
${ }^{5}$ The results are robust to clustering at bank and year, MSA, or MSA and year, level as shown in Section 6.2.
} 


\section{Results}

\subsection{Corporate intangible capital and bank asset allocations}

Table 2 presents the baseline results. The regressions explore the impact of corporate intangible capital on bank balance sheet components: C\&I loan growth (the key variable of interest, columns 1-3), total asset growth (columns 4-6), real estate loan growth (columns 7-9), and liquid asset growth (columns 10-12). For each dependent variable, the first specification includes the growth rate of corporate intangible capital, the second specification adds MSA- and bank-level controls, and the third specification adds year and bank fixed effects. The fixed effects control for yearly global shocks to all banks and unobserved time-invariant differences across banks in the growth rates of balance sheet components. All regressions for the growth rates of bank balance sheet components control for a bank's total asset growth, so the coefficients in columns 1-3 and 7-12 can be interpreted as relative growth rates.

The main result, consistent across specifications, is that an increase in the growth rate of corporate intangible capital is associated with a reduction in the growth rate of commercial loans for banks headquartered in the same MSA. Further, there is no change in total bank assets growth rate but there is an increase in the growth rate of real estate loans and liquid assets. To the extent that the macroeconomic controls appropriately capture MSA-level variables that drive demand for banks' non-C\&I lending, the results show that an increase in corporate intangible assets suppresses the growth rate of banks' C\&I loans and leads banks to reallocate their portfolios to non-C\&I assets, while having no effect on the size of bank balance sheets. This is the key result of the paper, and we seek to more closely explore its drivers and robustness further on.

The estimated coefficients on all macroeconomic controls have expected signs. Banks' total assets, commercial loans, and real estate loans grow faster in response to better local economic conditions (as measured by faster house price growth, per capital income and population growth, and firm sales growth). Liquid assets, in contrast, grow slower in response to better local economic conditions, consistent with better local lending opportunities for banks. For bank controls, we find that larger banks tend to grow slower, consistent with organizational diseconomies of scale, documented also in the previous literature (see, for example, Berger and Mester (1997)). Better capitalized banks have higher relative growth rates of commercial and real estate loans, but lower growth rates of liquid assets, consistent with bank capital offering banks more risk-taking capacity 
(liquid assets in our definition are predominantly safe assets). Larger banks, in contrast, tend to have lower growth rates of commercial and real estate loans, possibly because larger banks have on average less capital. (We return to the discussion of the relationship between bank capital and size and their impact on bank portfolio allocations in Section 4.2).

Table 3 considers the impact of corporate intangible capital on additional components of banks' balance sheets. The estimates indicate the effect of corporate intangible assets on the growth rate of bank real estate loans is similar for the residential real estate component (column 1) and the commercial real estate component (column 2). This finding is consistent with the possibility that firms with intangible assets respond to frictions in C\&I borrowing by pledging more of their commercial real estate. Column 3 establishes that banks do not expand consumer loans in response to higher corporate intangible assets, suggesting that banks are less likely to reallocate their resources toward unsecured lending.

Table 4 examines how the baseline relationship between corporate intangible assets and bank portfolio allocations varies with the size of the intangible capital growth rate. We distinguish between intangible capital growth rates that are above and below the median of the overall distribution of MSA-level intangible capital growth rates. ${ }^{6}$ The results are shown by splicing the intangible capital growth variable across the two subsamples. ${ }^{7}$ We find that the effects of intangible capital on bank portfolio components are statistically significant only for large (above-median) changes in MSA-level corporate intangible capital. The results in Table 4 provide further support to our baseline result that the reduction in commercial loan growth is indeed due to the rise in corporate intangible capital since large changes in intangible capital are relatively better proxies for fundamental changes in frictions in banks' lending to firms.

\subsection{Bank size and capital}

Table 5 explores heterogeneity in our baseline results along bank characteristics such as size and capitalization. We can expect stronger effects of corporate intangible capital for large banks because they may have relatively greater difficulty lending without hard collateral, since more information-

\footnotetext{
${ }^{6}$ Similar results, not shown, obtain for the intangible capital growth rates above and below the median for a given MSA.

${ }^{7}$ That is, we split the intangible capital growth variable into two variables that add up to the original variable: one variable whose values are replaced with zeros when intangible capital growth is below median (row 1), and another variable whose values are replaced with zeros when intangible capital growth is above median (row 2).
} 
intensive types of lending are less efficient in large organizations (Stein, 2002). Further, we can expect a weaker effect of corporate intangible capital for better capitalized banks, because such banks might be less averse to risks associated with lending without sufficient collateral due to greater loss-absorption capacity of higher capital.

We start by exploring the effects of bank size (columns 1, 4, 7, 10). We distinguish between banks with size above or below $\$ 90$ million (in 2010 U.S. dollars) in total assets (close to the median assets of $\$ 87$ million over the full sample). We present the results by splicing the intangible capital growth variable for banks that are above or below-median of the size distribution. The coefficients of interest on intangible asset growth for large banks are comparable to the point estimates in the full sample and statistically significant, while those for small banks have the expected sign but are imprecisely estimated. These estimates suggest that corporate intangible capital has a stronger effect on the portfolio allocations of large banks rather than those of small banks. ${ }^{8}$

Next, we perform a similar exercise, now distinguishing between banks with above- and belowmedian bank capital ratios (columns $2,5,8,11$ ). The average bank capital ratio is just above $12 \%$. Consistent with our hypothesis, we find that the growth of corporate intangible capital primarily affects banks with below-median capital.

Finally, we examine if the stronger effects for large banks are due to larger banks having less capital or due to bank size itself (columns 3, 6, 9, 12). We do so by splicing the intangible asset growth variable into four variables, respectively for large banks with low vs. high capital and small banks with low vs. high capital. The estimates indicate that the effects of intangible capital on the C\&I loan growth of both large and small banks are driven by those banks that have low capital (column 3). As such, the effects of bank size identified in column 1 seem to be driven by large banks having on average lower capital rather than by bank size. The p-value for a one-sided t-test confirms that the coefficients for large banks with low capital are statistically different in absolute value from those for large banks with high capital. Further, we find that, in response to corporate intangible capital shocks, banks with higher capital tend to reallocate their assets towards real estate loans (columns 8 and 9), while banks with lower capital reallocate to liquid assets (columns 11 and 12), consistent with higher-capital banks having more risk-taking capacity than lower-capital banks.

\footnotetext{
${ }^{8}$ This result is interesting because large banks are also more likely to have geographically diversified lending, and therefore for them our MSA-level bank-firm match should be less precise than for small banks. Therefore, these relatively larger effects may still understate the true impact of corporate intangible assets on large banks' portfolio allocations.
} 
The finding that larger bank size (through its association with lower bank capital) and lower bank capital amplify the effects of corporate intangible assets on bank portfolio allocations is important, because the pre-crisis period was characterized by long-term trends of bank consolidation and bank capital erosion (Alessandri and Haldane, 2009). These trends therefore may have amplified the economic effects of the secular increase in corporate intangible capital on the portfolio allocations of the banking system.

\section{Addressing Potential Omitted Variable Problems}

We interpret our baseline results as being driven by the fact that firms' intangible assets create frictions in banks' corporate lending, inducing banks to rebalance their portfolios towards nonC\&I assets. This interpretation however requires ruling out alternative explanations related to the general equilibrium effects of corporate intangible assets on the demand for non-C\&I loans. For example, more intangible firms may attract different types of employees, who may have higher demand for real estate or consumer loans, both of which are part of non-C\&I assets. We call this alternative explanation "the demand channel."

We aim to verify that our results are not driven by the demand channel is several ways. First, the baseline regressions control for MSA-level attributes that capture non-C\&I loan demand such as population, per capita household income, and house price growth. However, to the extent that our macro controls do not fully capture the demand for non-C\&I assets, the demand channel may confound our results as an omitted variable problem.

Therefore, to address potential concerns about this alternative channel, we deploy four further strategies. First, we control for all unobserved macroeconomic factors using MSA $\times$ year fixed effects. Second, we restrict the regressions to subsets of MSAs where intangible asset growth appears least related to proxies of demand for non-C\&I loans. Third, we consider the effects of corporate intangible asset growth on bank profitability. Fourth, in Section 6.1 we use the staggered timing of bank branching deregulation to assess whether the portfolio allocations of regulated vs. deregulated banks are consistent with the channel of interest or the demand channel. 


\subsection{Control for unobserved macro factors}

In Table 6 we estimate a specification with bank size and capital interactions (similar to that of Table 5) using MSA $\times$ year fixed effects instead of macro controls. The MSA $\times$ year fixed effects absorb all time-varying local economic conditions, including unobserved factors that may drive the demand for non-C\&I loans. Since the intangible asset growth variable itself varies at the MSA-year level, its coefficient cannot independently be estimated in a specification with MSA $\times$ year fixed effects. Instead, we focus on the interaction of intangible asset growth with bank size and capital, and examine whether these differential balance-sheet effects remain consistent with those found in Table 5. Consistent estimates between specifications with MSA macro controls and specifications with MSA $\times$ year fixed effects would suggest that the MSA macro controls used in the baseline analysis appropriately capture the local macroeconomic environment, including factors that may drive the demand channel. ${ }^{9}$

We find that the coefficients on the intangible capital growth interacted with the dummy for large bank size (holding low bank size as the base) are insignificant throughout (columns 1, 4, 7, 10), consistent with the fact that the coefficients for the impact of intangible capital growth for large and small banks in Table 5 (same respective columns) are not statistically different, based on the p-value of the F-test. In contrast, the coefficients on the intangible capital growth interacted with the dummy for low bank capital (holding high bank capital as base) are significant (columns 2, 5, 8, 11), consistent with the statistically different coefficients for the impact of intangible capital growth for banks with high and low capital in Table 5 based on the p-value of the F-test). The same holds when we interact intangible capital growth with indicators for large banks with low capital, large banks with high capital, and small banks with low capital (holding small banks with high capital as the base). Those coefficients that were different from the coefficient for small banks with high capital in Table 5 (columns 3, 6, 9, 12) are statistically significant in Table 6 as well. For example, both tables suggest that intangible asset growth affects commercial loan growth primarily for banks with low capital (columns 3 in both tables), leads to a contraction of assets of larger magnitude in all groups of banks compared to the contraction (or, indeed, the expansion) of assets in small banks with high capital (columns 6 of both tables), and that in response to corporate intangible asset growth banks with high capital reallocate their assets towards real estate loans whereas banks

\footnotetext{
${ }^{9}$ In all specifications we further control for interactions of house price growth with indicators of bank size and capital quantiles to allow for the demand channel to vary with bank conditions (see, e.g., Chakraborty et al. (2016)).
} 
with low capital reallocate to liquid assets (columns 6 and 12 in both tables). Furthermore, the point estimates of the coefficients in Table 6 are almost identical to the difference between the point estimates of the respective coefficients in Table 5.

Overall, the results in Tables 5 and 6 show that the estimated coefficients on the interaction of intangible assets and bank characteristics are virtually identical in terms of statistical significance and economic magnitudes when we use macro controls for local conditions vs. MSA $\times$ year fixed effects. It appears that the macro controls in the baseline specifications capture the effect of the whole range of relevant local economic conditions, which suggests that the omitted variable "demand channel" explanation is unlikely to be driving our main results.

\subsection{Exploit correlation of intangible assets and macro variables}

In the next test, we aim to reduce the impact or shut down the demand channel. To this end, we identify the subset of MSAs where corporate intangible capital growth is least related to several proxies of non-C\&I loan demand. We use the following demand proxies: (a) house prices, (b) per capita household income, (c) total household income (to account for changes in population). Figure 4 plots histograms for the cross-section of simple correlation coefficients between MSA-level corporate intangible capital growth and each demand proxy. Interestingly, each distribution has a negative mean and median (as reported in Panel $\mathrm{C}$ of Table 1), which already casts doubt on the possibility that corporate intangible capital growth is associated with greater demand for non-C\&I loans.

For the formal tests, we use the following criteria for "least relation" between corporate intangible capital growth and each non-C\&I loan demand proxy: (i) negative correlation between corporate intangible capital growth and the proxy, (ii) near-zero correlation (lower than 0.25 in absolute value), and (iii) a rejected hypothesis of Granger causality from corporate intangible capital growth to the proxy (at the $90 \%$ level of confidence). We re-run the baseline specification for the subsamples of MSAs defined from the above conditions. Each condition leads us to drop between one third and two thirds of the sample, potentially reducing the precision of our estimates.

Table 7 presents the results in summary form, reporting the coefficient estimate on the variable of interest (intangible capital growth), its standard error, and the number of observations in each regression. Across the board we find that the coefficients on corporate intangible capital growth 
remain significant, with point estimates close to those of the baseline specification in the full sample (Table 2). These results suggest that our findings in the baseline regressions are not driven by the MSAs with a high correlation between corporate intangible capital shocks and non-C\&I loan demand, such as housing. By contrast, our results seem to stem mainly from the MSAs where such correlation is low or even negative.

Table 8 presents estimates from regressions similar to those in Table 7 but now we restrict to MSAs that did not experience a house price boom in the 2000-2007 (columns 1-3) and the 19902007 (columns 4-6) periods. The first time period coincides with the nation-wide housing boom while the second period covers a large part of our sample while maintaining the widest availability of MSA-level house price data. We define "housing boom" MSA as those with house price growth above 50th (Panel A), 75th (Panel B), and 90th (Panel C) percentile across all MSAs. Once again we find that that in all MSAs without a housing boom the coefficients on intangible capital growth remain statistically significant, with point estimates close to those in the baseline specification in the full sample (Table 2), suggesting that our baseline results are not driven by MSAs which experienced a contemporaneous housing boom.

\subsection{Effects on bank profitability}

Table 9 offers an additional test aimed at ruling out the demand channel based on the effects of corporate intangible capital on bank profitability (as measured by net interest margins). If corporate intangible capital affects commercial loan growth through higher demand for non-C\&I loans, we would expect bank profitability to increase as a result of a positive demand shock. In contrast, if our hypothesized channel related to higher frictions in bank C\&I lending is at work, then bank profitability should suffer. The presentation of results in Table 9 is similar to that in Table 2, with column 1 showing a specification without any controls, column 2 adding macro controls, and column 3 adding bank and year fixed effects.

Across specifications, we find that higher intangible asset growth is associated with lower bank profitability. These results are consistent with the hypothesized channel but inconsistent with the demand channel. As a specification check, macro controls enter regressions with expected signs: better local conditions are associated with higher bank profitability (column 3). Larger banks and more rapidly growing banks are less profitable, consistent with lower margins on large-scale (not relationships-based) bank activities and in new markets. Finally, bank capitalization is positively 
related to bank profitability.

\section{Robustness Tests}

\subsection{The effects of bank branching deregulation}

Our analysis of the relationship between corporate intangible capital and bank portfolio allocations relies on establishing the bank-firm link at the MSA level, based on co-located headquarters. However, this link may be imprecise: banks can lend to firms that are located in different MSAs and firms can borrow from banks that are located in different MSAs. In this section we make this link more precise by exploiting a deregulation episode in the banking sector as a quasi-natural experiment.

In particular, we use the bank branching deregulation process to exploit banks' ability to lend outside their headquarters' MSA (state) and to establish differences in the impact of intangible capital for banks in pre-deregulated states compared to banks in deregulated states. Interstate bank branching deregulation took place from the mid-1970s to mid-1990s (Kroszner and Strahan, 1999). While pre-deregulation restrictions mostly concerned inbound branching from other states, most states had reciprocal agreements, so these restrictions simultaneously prevented local banks from expanding elsewhere. We take regulated branching as a proxy that banks in a given MSA are less likely to be able to conduct business elsewhere, i.e., that the MSA-level bank-firm link is more precise in pre-deregulation states.

The results of a differences-in-differences analysis for single-state MSAs are shown in Table 10. The coefficient estimates for the interaction terms "IK growth $\times$ Regulated" are consistent with a more precise bank-firm link: the relationship between corporate intangible assets and bank portfolio allocations was stronger in states with regulated bank branching. The coefficient estimates for MSAs in deregulated states (on the term "IK growth") are weaker yet also statistically significant at conventional level (in 5 of 6 specifications, columns 1-6), indicating a weaker yet present bankfirm link.

Conditioning on MSA with regulated branching offers an additional useful insight, as it allows us to reject the alternative explanation for the documented link between corporate intangible assets and bank portfolio allocations that is based on the demand for non-C\&I loans rather than fric- 
tions in C\&I lending. Just as regulated interstate branching restricts banks' ability to lend outside the headquarters MSA, it also restricts their ability to attract funding from outside that area. If corporate intangible assets had affected bank portfolios by increasing demand for non-C\&I loans, banks in regulated MSAs would have shifted relatively less to non-C\&I assets loans due to tighter funding constraints. We find that in fact they shifted more to non-C\&I assets. This is inconsistent with tighter funding constraints but consistent with a lower ability to reallocate C\&I lending geographically towards areas with slower growth of corporate intangible assets.

\subsection{Alternative specifications and further refinements}

We perform a range of robustness tests to verify that our results are robust to reasonable alternative specifications and refinements. The results are presented in the Appendix tables. Table A1 uses a measure of corporate intangible capital that excludes capitalized IT expenditure (columns 1-4). Since IT expenditure is only available at the industry level, this component of the intangible capital might be less precisely measured than the other components that are based on firm-level R\&D and SG\&A expenditures. The results are fully consistent with those from our main specification. They also remain robust to alternately using as dependent variables the two main components of intangible capital, namely capitalized R\&D expenditure (columns 5-8) and respectively capitalized SG\&A expenditure (columns 9-12).

Table A2 presents specifications that include the share of firms with a bond market rating in any given MSA-year (columns 1-4), which accounts for firms' access to alternative sources of financing. This control variable alleviates the potential concern that our results are driven by the development of securities markets that occurred simultaneously with the rise of intangible capital. We also report the results of our baseline regressions enriched with an MSA-level control variable for the number of patents, both unweighted and citation-weighted (columns 5-12), given that patents are an outcome of $R \& D$ activities that can potentially be pledged as collateral against bank loans. The coefficient estimates across columns indicate the relationship between corporate intangible assets and bank portfolio allocations continues to hold. They become less precise for liquid assets likely on account of a significant drop in sample size (columns 8,12), but remain close in magnitude to the baseline coefficient (Table 2, column 12).

In Table A3 we present specifications where the dynamics of bank portfolio allocations are captured not in growth rates, but in levels (columns 1-4) in specifications otherwise similar to the 
baseline. Then, we limit the sample to MSAs that headquarter at least 3 Compustat firms (the median number of Compustat firms per MSA is 5) in columns 5-8. Finally, we re-run our baseline specifications in a new dataset that matches banks and firms on state instead of MSA (columns 9-12). The results are again largely robust for these alternative approaches.

Our final robustness test pertains to the approach of estimating the standard errors. In our baseline regressions we clustered the standard errors at the bank level. In Table A4 we alternately cluster on bank and year (columns 1-4), on MSA (columns 5-8), and MSA and year (columns 912). We notice that the main coefficient estimates of interest, on intangible capital growth, remain statistically significant at conventional levels. In the three cases considered, for liquid assets the coefficients are statistically significant at the $15 \%$ level (columns 4, 8, 12).

\section{Conclusions}

This paper studies the effects of the corporate sector transition towards a greater use of intangible assets on bank lending. Consistent with intangible assets having lower collateral values, we find that increased corporate intangible capital leads banks to reallocate their portfolios from commercial loans towards non-C\&I assets, primarily real estate loans and liquid assets. Through multiple empirical tests we rule out an alternative channel where the reallocation is due to higher demand for non-C\&I loans instead of increased frictions in banks' commercial lending.

To our knowledge, this is the first paper to study how the share of intangible assets on corporate balance sheets, a rising trend since at least the late 1970s, affects the structure of bank balance sheets. We find that in response to the rise in corporate intangible assets, banks do not shrink their balance sheets but rather reallocate their lending capacity away from commercial loans, and primarily towards real estate and liquid assets. Overall, our estimates suggest that the rise in corporate intangible assets since the late 1970s may account for up to $20 \%$ of bank portfolio reallocation from commercial loans to real estate loans and liquid assets over the same period.

Our findings shed light on possible reasons for a supply-driven boom in real estate lending in the run-up to the 2007-2008 crisis, for increased safe asset demand in the 2000s (Gorton and Ordonez, 2013), and a "banking glut" (Shin, 2012). The finding that the rise in corporate intangible capital affects primarily large and less well capitalized banks suggests that the trends towards bank consolidation and bank capital erosion since the 1990s may have amplified the impact of corporate 
intangible assets on bank portfolios. Our analysis suggests that the change in the asset composition in the corporate sector has resulted in a significant shift in the asset composition of the banking sector over the last four decades.

At the macroeconomic level, greater intermediation frictions stemming from corporate intangible assets might lead to a rise in the demand for safe assets. On the one hand, corporate savings increase in expectation of difficulties in obtaining external funding. The need to invest these funds into liquid and relatively safe securities may lead to increased demand from the corporate sector for MBS and sovereign bonds. On the other hand, banks deprived of lending opportunities in the corporate sector may also increase their demand for such assets. In this context, our findings may provide a complementary explanation to the secular decline in safe yields that is at the center of the debate on secular stagnation (Summers, 2015). 


\section{References}

Alessandri, P. and Haldane, A. G. (2009). Banking on the state. Speech delivered at the Federal Reserve Bank of Chicago 12th Annual International Banking Conference, Nov 6.

Bates, T. W., Kahle, K. M., and Stulz, R. M. (2009). Why do US firms hold so much more cash than they used to? The Journal of Finance, 64(5):1985-2021.

Berger, A. N. and Mester, L. J. (1997). Inside the black box: What explains the differences in the efficiencies of financial institutions? Journal of Banking and Finance, 21:895-947.

Berger, A. N. and Udell, G. F. (1990). Collateral, loan quality and bank risk. Journal of Monetary Economics, 25(1):21-42.

Bester, H. (1985). Screening vs. rationing in credit markets with imperfect information. The American Economic Review, 75(4):850-855.

Brown, J. R., Fazzari, S. M., and Petersen, B. C. (2009). Financing innovation and growth: Cash flow, external equity, and the 1990s R\&D boom. The Journal of Finance, 64(1):151-185.

Brown, J. R., Martinsson, G., and Petersen, B. C. (2013). Law, stock markets, and innovation. The Journal of Finance, 68(4):1517-1549.

Caggese, A. and Perez, A. (2016). Reallocation of intangible capital and secular stagnation.

Carpenter, R. E. and Petersen, B. C. (2002). Capital market imperfections, high-tech investment, and new equity financing. The Economic Journal, 112(477):F54-F72.

Chakraborty, I., Goldstein, I., and MacKinlay, A. (2016). Housing price booms and crowding-out effects in bank lending.

Chan, Y.-S. and Thakor, A. V. (1987). Collateral and competitive equilibria with moral hazard and private information. The Journal of Finance, 42(2):345-363.

Chava, S., Oettl, A., Subramanian, A., and Subramanian, K. V. (2013). Banking deregulation and innovation. Journal of Financial Economics, 109(3):759-774.

Corrado, C., Hulten, C., and Sichel, D. (2005). Measuring capital and technology: An expanded framework. In Measuring capital in the new economy, pages 11-46. University of Chicago Press.

Corrado, C., Hulten, C., and Sichel, D. (2009). Intangible capital and US economic growth. Review of Income and Wealth, 55(3):661-685.

Corrado, C. A. and Hulten, C. R. (2010). How Do You Measure a "Technological Revolution"? The American Economic Review, 100(2):99-104.

Cortés, K. R. and Strahan, P. E. (2015). Tracing out capital flows: How financially integrated banks respond to natural disasters. Journal of Financial Economics, forthcoming.

Döttling, R. and Perotti, E. (2016). Secular financial trends and technological progress.

Eisfeldt, A. L. and Papanikolaou, D. (2013). Organization capital and the cross-section of expected returns. The Journal of Finance, 68(4):1365-1406. 
Falato, A., Kadyrzhanova, D., and Sim, J. (2013). Rising intangible capital, shrinking debt capacity, and the US corporate savings glut.

Gorton, G. B. and Ordonez, G. (2013). The supply and demand for safe assets. Technical report, National Bureau of Economic Research.

Hall, B. H., Jaffe, A. B., and Trajtenberg, M. (2001). The NBER patent citation data file: Lessons, insights and methodological tools. NBER Working Paper No. 8498.

Hart, O. and Moore, J. (1994). A theory of debt based on the inalienability of human capital. The Quarterly Journal of Economics, 109(4):841-879.

Kroszner, R. S. and Strahan, P. E. (1999). What drives deregulation? Economics and politics of the relaxation of bank branching restrictions. The Quarterly Journal of Economics, 114(4):14371467.

Lev, B. and Radhakrishnan, S. (2005). The valuation of organization capital. In Measuring capital in the new economy, pages 73-110. University of Chicago Press.

Loumioti, M. (2012). The use of intangible assets as loan collateral. Available at SSRN 1748675.

Loutskina, E. and Strahan, P. E. (2009). Securitization and the declining impact of bank finance on loan supply: Evidence from mortgage originations. The Journal of Finance, 64(2):861-889.

Mann, W. (2015). Creditor rights and innovation: Evidence from patent collateral. Available at SSRN 2356015.

Rajan, R. and Winton, A. (1995). Covenants and collateral as incentives to monitor. The Journal of Finance, 50(4):1113-1146.

Shin, H. S. (2012). Global banking glut and loan risk premium. IMF Economic Review, 60(2):155192.

Stein, J. C. (2002). Information production and capital allocation: Decentralized versus hierarchical firms. The Journal of Finance, 57(5):1891-1921.

Summers, L. H. (2015). Demand side secular stagnation. The American Economic Review, 105(5):60-65. 
Figures and tables

Figure 1: Corporate intangible assets and bank C\&I loans, 1977-2010

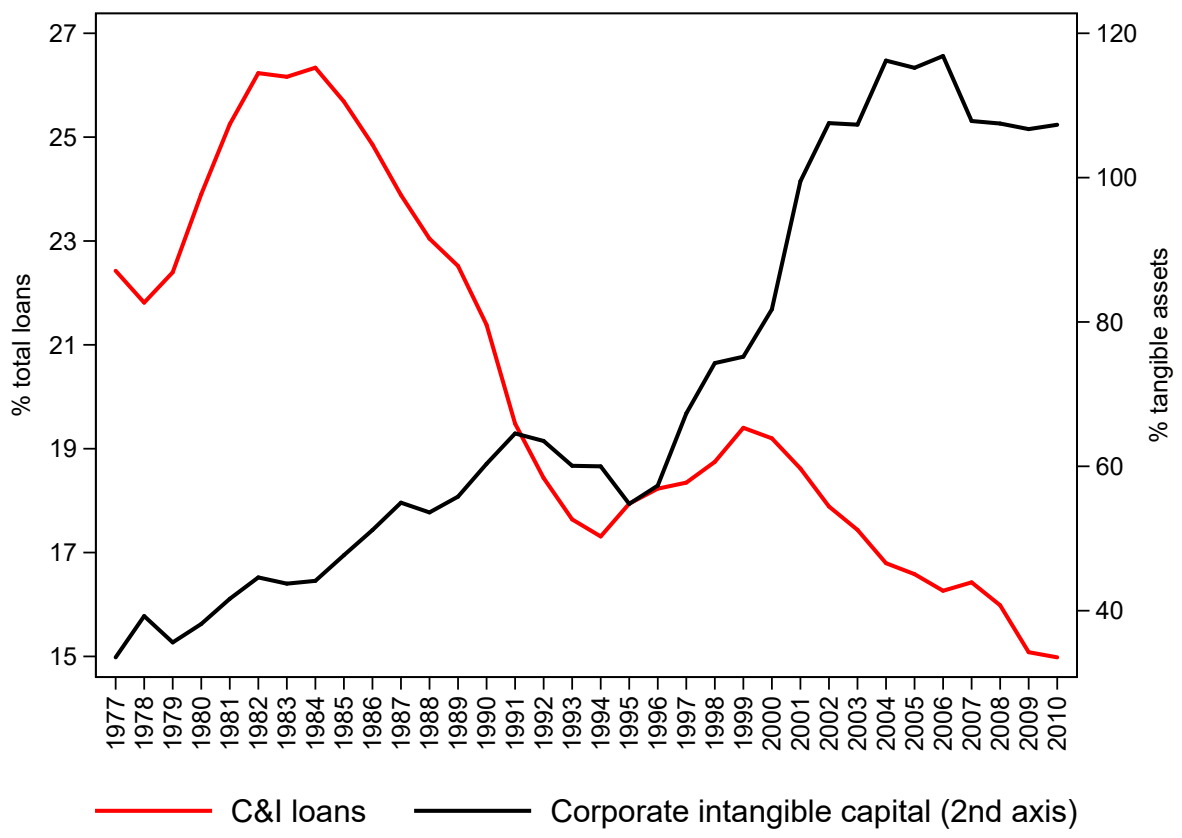

Notes: The figure plots the average share of corporate intangible capital in total assets for US Compustat firms; and the average share of C\&I loans in total loans for US commercial banks during 1977-2010. Data sources: Compustat, US Call Reports. 
Figure 2: Corporate intangible assets, and bank loan portfolios, 1977-2010

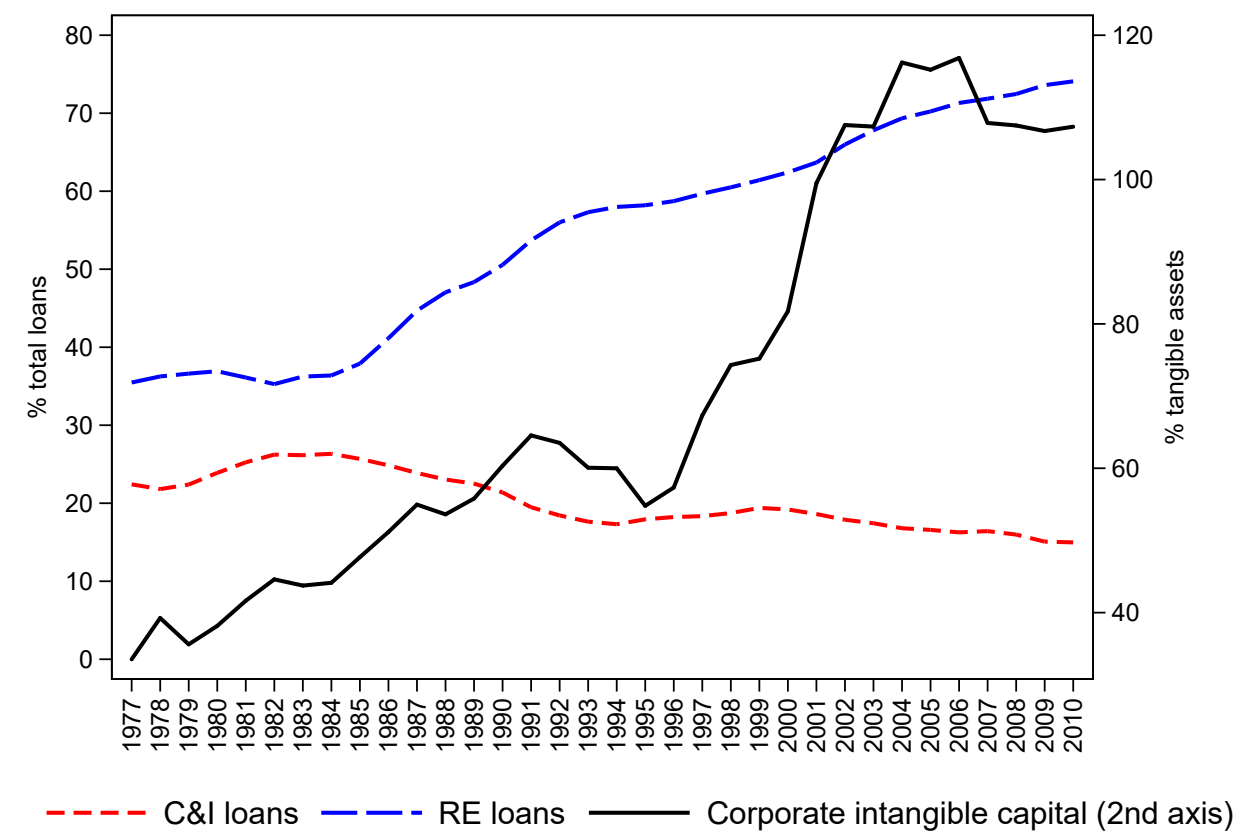

Notes: The figure plots the average share of corporate intangible capital in total assets for US Compustat firms; the average share of C\&I loans in total loans; and the average share of real estate (RE) loans in total loans for US commercial banks during 1977-2010. Data sources: Compustat, US Call Reports. 
Figure 3: Growth rate of corporate intangible assets, 1977-2010

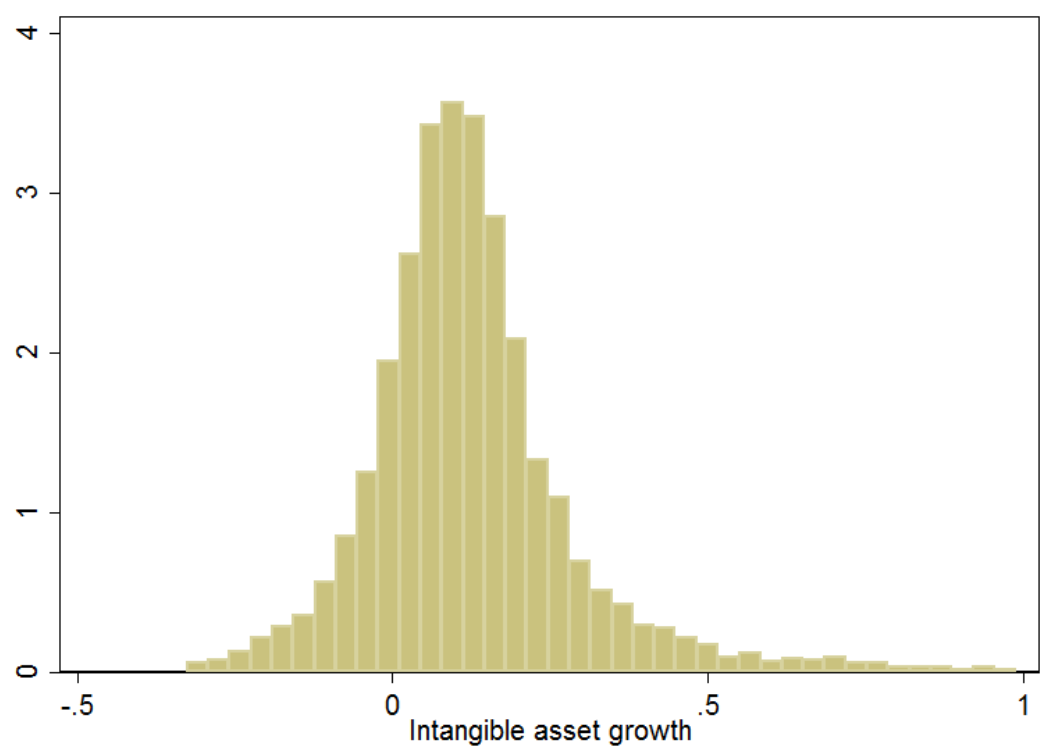

(a) Histogram

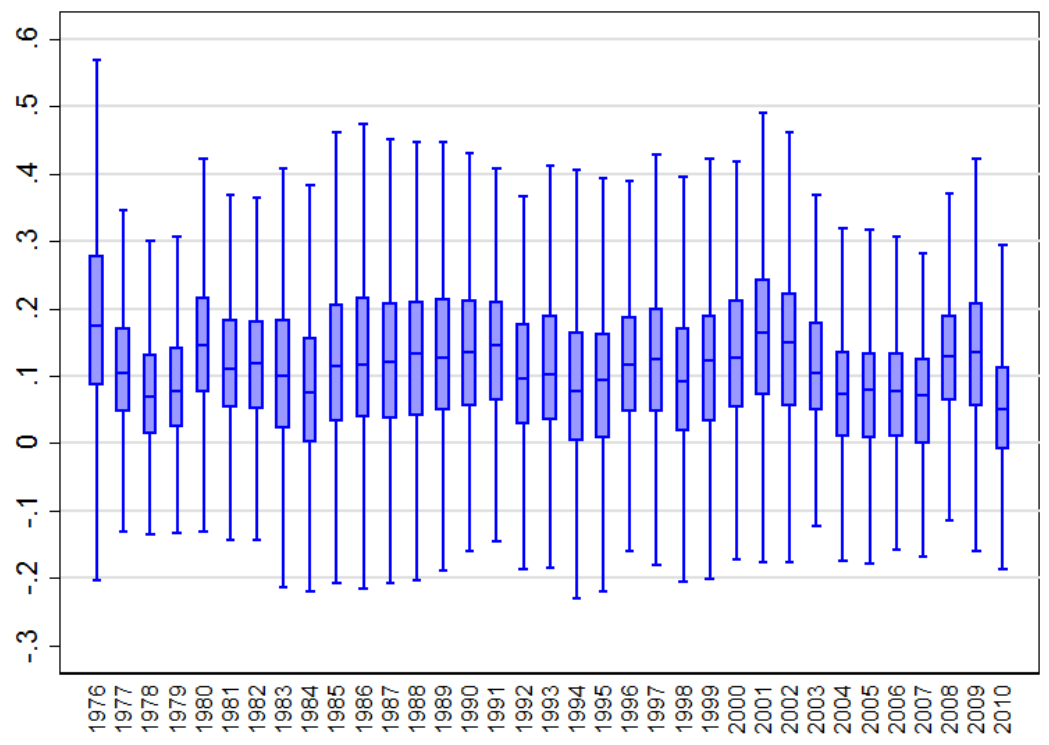

(b) Time-series

Notes: Panel A plots a histogram of the growth rate of corporate intangible capital in the pooled MSA-year panel over 1977-2010. Panel B depicts the yearly distribution of the growth rate of corporate intangible assets at the MSA level over 1977-2010. Data sources: Compustat. 
Figure 4: Correlations of corporate intangible assets and macro variables, 1977-2010

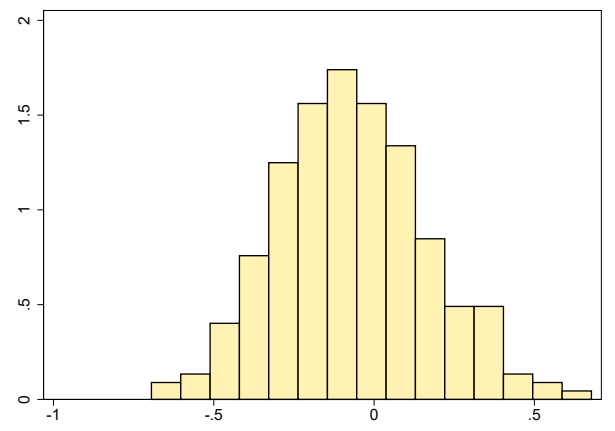

(a) IK growth and HP growth

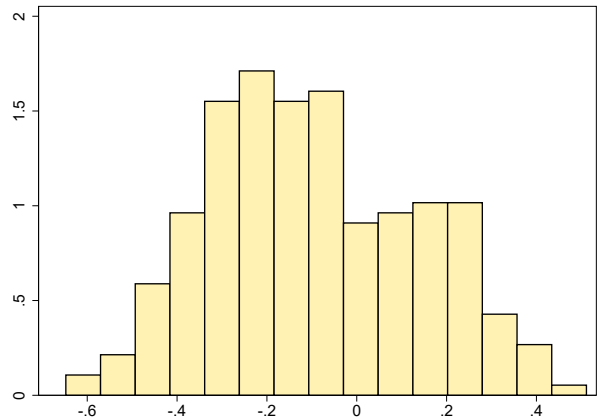

(b) IK growth and pc income growth

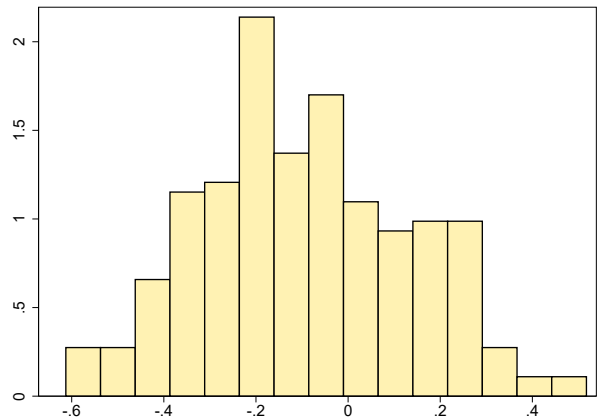

(c) IK growth and total MSA income growth

Notes: The figure shows histograms of the simple correlation coefficients between intangible asset growth on the one hand and, respectively, house price growth (Panel A), per capita household income growth (Panel B), and total (MSA-level) household income growth (Panel C) on the other hand. The correlations are computed for each MSA over 1977-2010 or the available period (conditional on observing at least 10 consecutive observations). 
Table 1: Descriptive statistics

\begin{tabular}{|c|c|c|c|c|c|c|c|c|}
\hline & No. obs & Mean & St. Dev. & Min & $\mathrm{p} 25$ & Median & p75 & Max \\
\hline \multicolumn{9}{|l|}{ A. Selected regression variables } \\
\hline IK growth & 109,710 & $14.7 \%$ & $13.9 \%$ & $-31.8 \%$ & $8.3 \%$ & $13.8 \%$ & $19.6 \%$ & $102.3 \%$ \\
\hline IK (no IT) growth & 109,710 & $15.4 \%$ & $14.6 \%$ & $-32.8 \%$ & $8.7 \%$ & $14.3 \%$ & $20.6 \%$ & $106.6 \%$ \\
\hline IK (R\&D) growth & 102,393 & $11.9 \%$ & $16.9 \%$ & $-40.3 \%$ & $4.0 \%$ & $11.3 \%$ & $18.4 \%$ & $118.9 \%$ \\
\hline IK (SG\&A) growth & 109,710 & $15.4 \%$ & $14.5 \%$ & $-32.8 \%$ & $8.5 \%$ & $14.4 \%$ & $20.5 \%$ & $105.4 \%$ \\
\hline C\&I loan growth & 100,115 & $6.6 \%$ & $24.2 \%$ & $-40.4 \%$ & $-9.9 \%$ & $3.5 \%$ & $19.4 \%$ & $91.8 \%$ \\
\hline Real estate loan growth & 101,855 & $8.7 \%$ & $16.6 \%$ & $-20.3 \%$ & $-2.9 \%$ & $6.0 \%$ & $17.2 \%$ & $70.0 \%$ \\
\hline Residential real estate loan growth & 99,991 & $8.0 \%$ & $19.8 \%$ & $-25.7 \%$ & $-5.4 \%$ & $4.2 \%$ & $17.1 \%$ & $86.0 \%$ \\
\hline Commercial real estate loan growth & 99,375 & $10.8 \%$ & $25.0 \%$ & $-33.8 \%$ & $-6.2 \%$ & $6.6 \%$ & $22.5 \%$ & $109.9 \%$ \\
\hline Consumer loan growth & 98,981 & $0.8 \%$ & $18.4 \%$ & $-34.1 \%$ & $-12.0 \%$ & $-1.3 \%$ & $10.9 \%$ & $62.1 \%$ \\
\hline Liquid asset growth & 86,526 & $4.7 \%$ & $18.3 \%$ & $-30.5 \%$ & $-8.3 \%$ & $2.4 \%$ & $15.5 \%$ & $60.8 \%$ \\
\hline Bank asset growth & 109,710 & $5.1 \%$ & $9.0 \%$ & $-10.6 \%$ & $-1.3 \%$ & $3.6 \%$ & $10.0 \%$ & $33.6 \%$ \\
\hline Net interest margin growth & 76,610 & $-2.5 \%$ & $8.1 \%$ & $-20.2 \%$ & $-8.2 \%$ & $-3.0 \%$ & $2.6 \%$ & $20.8 \%$ \\
\hline HP growth & 109,710 & $4.4 \%$ & $6.0 \%$ & $-35.0 \%$ & $1.5 \%$ & $4.1 \%$ & $6.7 \%$ & $41.2 \%$ \\
\hline Pc income growth & 109,710 & $5.5 \%$ & $3.7 \%$ & $-15.2 \%$ & $3.4 \%$ & $5.2 \%$ & $7.3 \%$ & $53.0 \%$ \\
\hline Population growth & 109,710 & $1.5 \%$ & $1.5 \%$ & $-18.5 \%$ & $0.6 \%$ & $1.2 \%$ & $2.1 \%$ & $11.0 \%$ \\
\hline Firms' sales growth & 109,710 & $10.6 \%$ & $14.0 \%$ & $-38.6 \%$ & $3.4 \%$ & $10.1 \%$ & $16.6 \%$ & $112.6 \%$ \\
\hline Bank size (log-assets) & 109,710 & 17.99 & 1.26 & 14.13 & 17.13 & 17.85 & 18.66 & 25.14 \\
\hline Bank capital & 109,454 & $12.7 \%$ & $7.1 \%$ & $-14.2 \%$ & $7.9 \%$ & $11.3 \%$ & $15.9 \%$ & $100.0 \%$ \\
\hline$\%$ rated firms & 109,710 & $16.4 \%$ & $19.4 \%$ & $0.0 \%$ & $0.0 \%$ & $13.5 \%$ & $26.0 \%$ & $100.0 \%$ \\
\hline Regulated & 71,201 & $38.8 \%$ & - & 0.00 & - & - & - & 1.00 \\
\hline \multicolumn{9}{|l|}{ B. Selected variables in levels (\% assets) } \\
\hline $\mathrm{IK}$ & 109,710 & $67.8 \%$ & $67.3 \%$ & $0.8 \%$ & $34.9 \%$ & $50.4 \%$ & $76.5 \%$ & $1428.3 \%$ \\
\hline C\&I loans & 109,710 & $12.1 \%$ & $8.8 \%$ & $0.0 \%$ & $5.8 \%$ & $10.2 \%$ & $16.4 \%$ & $100.0 \%$ \\
\hline Real estate loans & 109,710 & $32.2 \%$ & $17.0 \%$ & $0.0 \%$ & $19.3 \%$ & $29.8 \%$ & $43.3 \%$ & $100.0 \%$ \\
\hline Liquid assets & 99,819 & $34.6 \%$ & $15.5 \%$ & $0.0 \%$ & $23.8 \%$ & $33.4 \%$ & $44.1 \%$ & $100.0 \%$ \\
\hline \multicolumn{9}{|l|}{ C. Within-MSA correlations } \\
\hline B/w IK \& HPs & 245 & -0.070 & 0.234 & -0.695 & -0.233 & -0.077 & 0.085 & 0.678 \\
\hline $\mathrm{B} / \mathrm{w}$ IK \& pc hh income & 242 & -0.095 & 0.234 & -0.648 & -0.266 & -0.127 & 0.096 & 0.511 \\
\hline B/w IK \& total hh income & 242 & -0.092 & 0.228 & -0.613 & -0.257 & -0.121 & 0.072 & 0.517 \\
\hline
\end{tabular}

Notes: The descriptive statistics are shown for the regression sample (Panels A, B) and in the MSA cross-section (Panel C). Growth rates of bank and firm balance sheet variables are winsorized and trimmed at the 5th and 95th percentiles. Intangible capital growth is winsorized at the 1st and 99th percentile of the firm-level distribution, before aggregating at the MSA level. Firm-level variables such as intangible capital growth and sales growth are computed at the MSA level as simple averages across the firms that are headquartered in each MSA. Intangible capital and its components are scaled by total book assets. Panel C reports the simple MSA-level correlation coefficients between intangible capital growth and respectively three macroeconomic variables, also in growth rates. Data sources: See Table A1. 
Table 2: Corporate intangible capital and bank portfolio allocations-Baseline

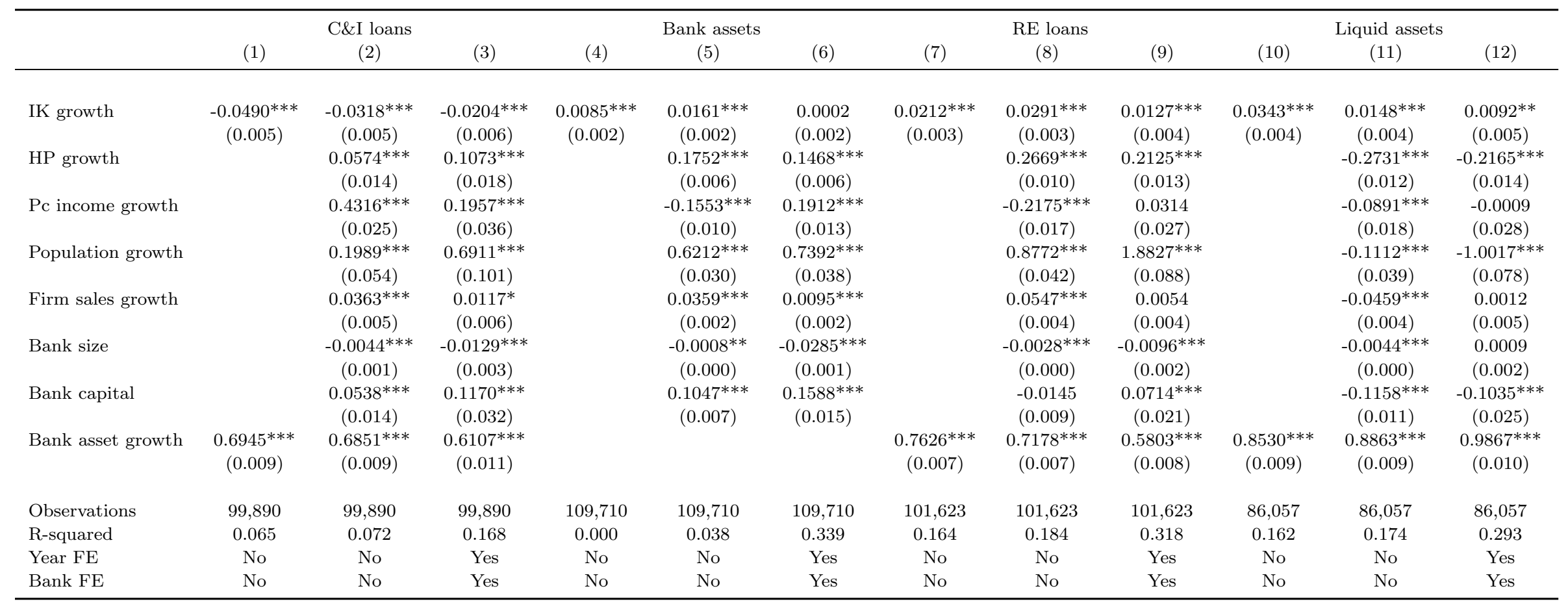

Notes: The dependent variable is bank-level C\&I loan growth (columns 1-3), total asset growth (columns 4-6), real estate loan growth (columns 7-9), and liquid asset growth (columns 8-10). The regressions are run in a bank-level panel over 1977-2010. Intangible capital growth, house price growth, per capital income growth, population growth, and firm sales growth are at the MSA level. Bank size, capital, and total asset growth are at the bank level. Standard errors are clustered on bank. *** indicates statistical significance at the $1 \%$ level, ${ }^{* *}$ at the $5 \%$ level, and $*$ at the $10 \%$ level. 
Table 3: Corporate intangible capital and the components of non-C\&I loans

\begin{tabular}{|c|c|c|c|}
\hline & $\begin{array}{c}\text { Residential real } \\
\text { estate loans } \\
\text { (1) }\end{array}$ & $\begin{array}{c}\text { Commercial real } \\
\text { estate loans } \\
(2)\end{array}$ & $\begin{array}{c}\text { Consumer } \\
\text { loans } \\
(3)\end{array}$ \\
\hline IK growth & $\begin{array}{c}0.0111^{* *} \\
(0.005)\end{array}$ & $\begin{array}{c}0.0113^{*} \\
(0.006)\end{array}$ & $\begin{array}{c}-0.0083^{*} \\
(0.005)\end{array}$ \\
\hline HP growth & $\begin{array}{c}0.1745^{* * *} \\
(0.017)\end{array}$ & $\begin{array}{c}0.2424^{* * *} \\
(0.019)\end{array}$ & $\begin{array}{c}0.1669^{* * *} \\
(0.015)\end{array}$ \\
\hline Pc income growth & $\begin{array}{r}-0.0365 \\
(0.034)\end{array}$ & $\begin{array}{l}0.0482 \\
(0.040)\end{array}$ & $\begin{array}{c}0.1323^{* * *} \\
(0.027)\end{array}$ \\
\hline Population growth & $\begin{array}{c}1.5087^{* * *} \\
(0.107)\end{array}$ & $\begin{array}{c}1.7594^{* * *} \\
(0.118)\end{array}$ & $\begin{array}{c}0.2109^{* * *} \\
(0.078)\end{array}$ \\
\hline Firm sales growth & $\begin{array}{l}0.0005 \\
(0.005)\end{array}$ & $\begin{array}{c}0.0162^{* * *} \\
(0.006)\end{array}$ & $\begin{array}{c}0.0090^{*} \\
(0.005)\end{array}$ \\
\hline Bank size & $\begin{array}{c}-0.0111^{* * *} \\
(0.002)\end{array}$ & $\begin{array}{c}-0.0083^{* * *} \\
(0.003)\end{array}$ & $\begin{array}{c}-0.0198^{* * *} \\
(0.002)\end{array}$ \\
\hline Bank capital & $\begin{array}{l}0.0383 \\
(0.027)\end{array}$ & $\begin{array}{l}0.0287 \\
(0.033)\end{array}$ & $\begin{array}{c}0.0561^{* *} \\
(0.026)\end{array}$ \\
\hline Bank asset growth & $\begin{array}{c}0.4844^{* * *} \\
(0.010)\end{array}$ & $\begin{array}{c}0.5635^{* * *} \\
(0.012)\end{array}$ & $\begin{array}{c}0.4058^{* * *} \\
(0.009)\end{array}$ \\
\hline Observations & 96,199 & 95,567 & 98,657 \\
\hline R-squared & 0.231 & 0.214 & 0.217 \\
\hline Year FE & Yes & Yes & Yes \\
\hline Bank FE & Yes & Yes & Yes \\
\hline
\end{tabular}

Notes: The dependent variables represent components of non-C\&I lending, respectively residential real estate loan growth (column 1), commercial real estate loan growth (column 2), and consumer loan growth (column 3). The regressions are run in a bank-level panel over 1977-2010. Intangible capital growth, house price growth, per capital income growth, population growth, and firm sales growth are at the MSA level. Bank size, capital, and total asset growth are at the bank level. Standard errors are clustered on bank. ${ }^{* * *}$ indicates statistical significance at the $1 \%$ level, ${ }^{* *}$ at the $5 \%$ level, and ${ }^{*}$ at the $10 \%$ level. 
Table 4: Corporate intangible capital and bank portfolio allocations-High vs. low changes in intangible capital

\begin{tabular}{|c|c|c|c|c|}
\hline & $\begin{array}{c}\text { C\&I loans } \\
(1)\end{array}$ & $\begin{array}{c}\text { Bank assets } \\
(2)\end{array}$ & $\begin{array}{c}\text { Real estate loans } \\
\text { (3) }\end{array}$ & $\begin{array}{l}\text { Liquid assets } \\
\text { (4) }\end{array}$ \\
\hline IK growth > p50 [1] & $\begin{array}{c}-0.0254^{* * *} \\
(0.006)\end{array}$ & $\begin{array}{l}-0.0004 \\
(0.002)\end{array}$ & $\begin{array}{c}0.0144^{* * *} \\
(0.004)\end{array}$ & $\begin{array}{c}0.0119 * * \\
(0.005)\end{array}$ \\
\hline IK growth < p50 [2] & $\begin{array}{c}0.0349 * * \\
(0.015)\end{array}$ & $\begin{array}{l}0.0068 \\
(0.005)\end{array}$ & $\begin{array}{l}-0.0057 \\
(0.009)\end{array}$ & $\begin{array}{l}-0.0183 \\
(0.011)\end{array}$ \\
\hline HP growth & $\begin{array}{c}0.1050^{* * *} \\
(0.018)\end{array}$ & $\begin{array}{c}0.1465^{* * *} \\
(0.006)\end{array}$ & $\begin{array}{c}0.2132^{* * *} \\
\quad(0.013)\end{array}$ & $\begin{array}{c}-0.2157^{* * *} \\
(0.014)\end{array}$ \\
\hline Pc income growth & $\begin{array}{c}0.1882^{* * *} \\
(0.036)\end{array}$ & $\begin{array}{c}0.1904^{* * *} \\
(0.013)\end{array}$ & $\begin{array}{l}0.0341 \\
(0.027)\end{array}$ & $\begin{array}{l}0.0023 \\
(0.028)\end{array}$ \\
\hline Population growth & $\begin{array}{c}0.7018^{* * *} \\
(0.101)\end{array}$ & $\begin{array}{c}0.7405^{* * *} \\
(0.038)\end{array}$ & $\begin{array}{c}1.8790^{* * *} \\
(0.088)\end{array}$ & $\begin{array}{c}-1.0072^{* * *} \\
(0.078)\end{array}$ \\
\hline Firm sales growth & $\begin{array}{c}0.0129 * * \\
(0.006)\end{array}$ & $\begin{array}{c}0.0096^{* * *} \\
(0.002)\end{array}$ & $\begin{array}{l}0.0049 \\
(0.004)\end{array}$ & $\begin{array}{l}0.0004 \\
(0.005)\end{array}$ \\
\hline Bank size & $\begin{array}{c}-0.0129 * * * \\
(0.003)\end{array}$ & $\begin{array}{c}-0.0285^{* * *} \\
(0.001)\end{array}$ & $\begin{array}{c}-0.0096^{* * *} \\
(0.002)\end{array}$ & $\begin{array}{l}0.0010 \\
(0.002)\end{array}$ \\
\hline Bank capital & $\begin{array}{c}0.1166^{* * *} \\
(0.032)\end{array}$ & $\begin{array}{c}0.1587^{* * *} \\
(0.015)\end{array}$ & $\begin{array}{c}0.0715^{* * *} \\
(0.021)\end{array}$ & $\begin{array}{c}-0.1031^{* * *} \\
(0.025)\end{array}$ \\
\hline Bank asset growth & $\begin{array}{c}0.6105^{* * *} \\
(0.011)\end{array}$ & & $\begin{array}{c}0.5803^{* * *} \\
(0.008)\end{array}$ & $\begin{array}{c}0.9868^{* * *} \\
(0.010)\end{array}$ \\
\hline Observations & 99,890 & 109,710 & 101,623 & 86,057 \\
\hline R-squared & 0.168 & 0.339 & 0.318 & 0.293 \\
\hline Year FE & Yes & Yes & Yes & Yes \\
\hline Bank FE & Yes & Yes & Yes & Yes \\
\hline $\mathrm{p}$-value t-test $[1]=[2]$ & 0.000 & 0.149 & 0.033 & 0.008 \\
\hline
\end{tabular}

Notes: The dependent variables are bank-level C\&I loan growth (column 1), total asset growth (column 2), real estate loan growth (column 3), and liquid asset growth (column 4). The regressions are run in a bank-level panel over 1977-2010. Intangible capital growth, house price growth, per capital income growth, population growth, and firm sales growth are at the MSA level. Bank size, capital, and total asset growth are at the bank level. Standard errors are clustered on bank. *** indicates statistical significance at the $1 \%$ level, ${ }^{* *}$ at the $5 \%$ level, and * at the $10 \%$ level. 
Table 5: Corporate intangible capital and bank portfolio allocations - Heterogeneity by bank size and capital

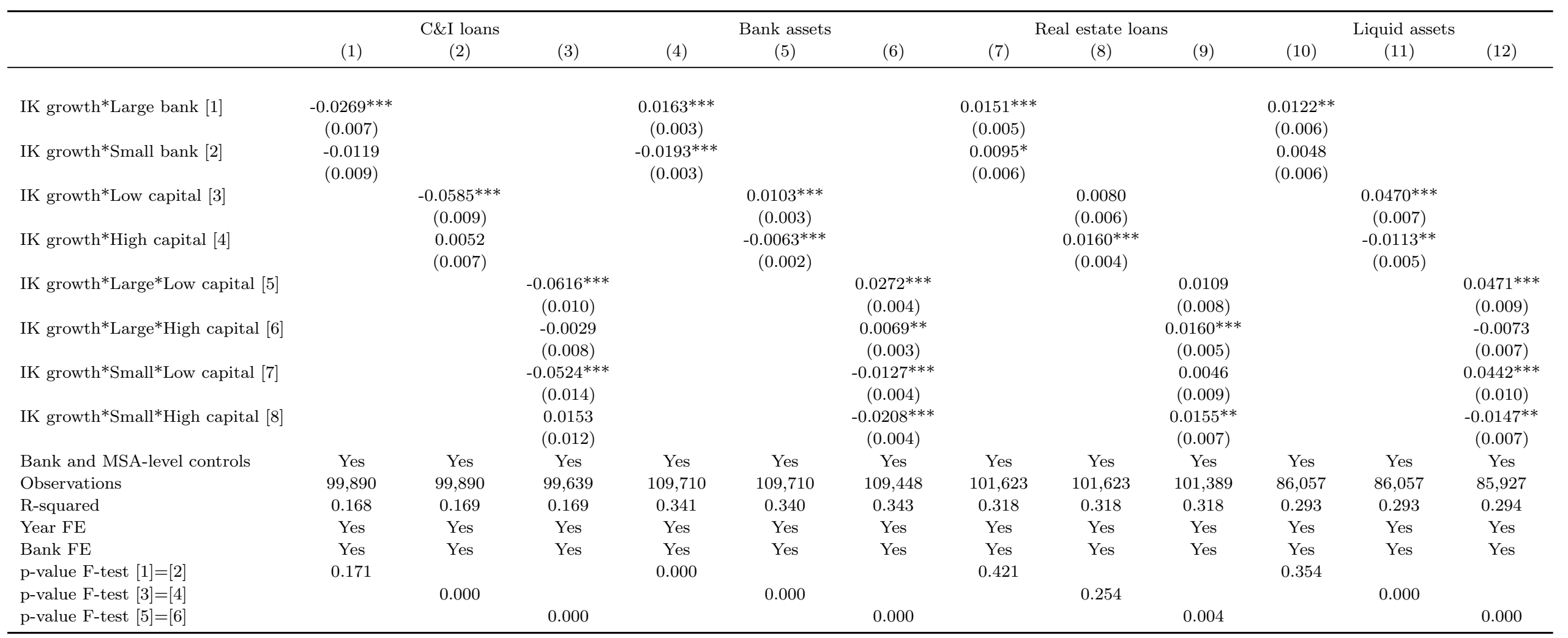

Notes: The dependent variables are bank-level C\&I loan growth (columns 1-3), total asset growth (columns 4-6), real estate loan growth (columns 7-9), and liquid asset growth (columns 10-12). The regressions are run in a bank-level panel over 1977-2010. Large banks have total assets larger than 90 million U.S. dollars (in constant 2010 prices). Intangible capital growth, house price growth, per capital income growth, population growth, and firm sales growth are at the MSA level. Bank size, capital, and total asset growth are at the bank level. All regressions include bank and MSA level controls as in the baseline regressions (Table 2), as well as 8 additional interaction terms of bank capital and size and house price growth. Standard errors are clustered on bank. *** indicates statistical significance at the $1 \%$ level, $* *$ at the $5 \%$ level, and $*$ at the $10 \%$ level. 
Table 6: Corporate intangible capital and bank portfolio allocations-Heterogeneity by bank size and capital

\begin{tabular}{|c|c|c|c|c|c|c|c|c|c|c|c|c|}
\hline & & \multicolumn{3}{|c|}{ Bank assets } & \multicolumn{3}{|c|}{ Real estate loans } & \multicolumn{3}{|c|}{ Liquid assets } \\
\hline & $(1)$ & $(2)$ & $(3)$ & $(4)$ & $(5)$ & $(6)$ & $(7)$ & $(8)$ & (9) & $(10)$ & $(11)$ & $(12)$ \\
\hline IK growth*Large bank & $\begin{array}{c}-0.0182 \\
(0.012)\end{array}$ & & & $\begin{array}{c}-0.0063 \\
(0.004)\end{array}$ & & & $\begin{array}{l}-0.0023 \\
(0.008)\end{array}$ & & & $\begin{array}{l}0.0023 \\
(0.009)\end{array}$ & & \\
\hline IK growth*Low capital & & $\begin{array}{c}-0.0525^{* * *} \\
(0.014)\end{array}$ & & & $\begin{array}{c}-0.0086^{*} \\
(0.005)\end{array}$ & & & $\begin{array}{c}-0.0316^{* * *} \\
(0.009)\end{array}$ & & & $\begin{array}{c}0.0660^{* * *} \\
(0.011)\end{array}$ & \\
\hline IK growth*Large*Low capital & & & $\begin{array}{c}-0.0615^{* * *} \\
(0.017)\end{array}$ & & & $\begin{array}{c}-0.0135^{* *} \\
(0.006)\end{array}$ & & & $\begin{array}{c}-0.0343^{* * *} \\
(0.011)\end{array}$ & & & $\begin{array}{c}0.0637^{* * * *} \\
(0.014)\end{array}$ \\
\hline IK growth*Large*High capital & & & $\begin{array}{c}-0.0104 \\
(0.016)\end{array}$ & & & $\begin{array}{c}-0.0168^{* * *} \\
(0.005)\end{array}$ & & & $\begin{array}{c}-0.0006 \\
(0.009)\end{array}$ & & & $\begin{array}{c}-0.0066 \\
(0.011)\end{array}$ \\
\hline IK growth*Small*Low capital & & & $\begin{array}{c}-0.0518^{* * *} \\
(0.018)\end{array}$ & & & $\begin{array}{c}-0.0189^{* * * *} \\
(0.006)\end{array}$ & & & $\begin{array}{c}-0.0279^{* *} \\
(0.012)\end{array}$ & & & $\begin{array}{c}0.0629^{* * *} \\
(0.013)\end{array}$ \\
\hline HP growth*Large bank & $\begin{array}{l}0.0373 \\
(0.033)\end{array}$ & & & $\begin{array}{l}0.0115 \\
(0.012)\end{array}$ & & & $\begin{array}{c}0.1101^{* * * *} \\
(0.022)\end{array}$ & & & $\begin{array}{c}-0.0252 \\
(0.023)\end{array}$ & & \\
\hline HP growth*Low capital & & $\begin{array}{l}0.0540 \\
(0.049)\end{array}$ & & & $\begin{array}{c}0.1978^{* * *} \\
(0.018)\end{array}$ & & & $\begin{array}{c}0.1045^{* * *} \\
(0.035)\end{array}$ & & & $\begin{array}{r}-0.0535 \\
(0.039)\end{array}$ & \\
\hline HP growth*Large*Low capital & & & $\begin{array}{l}0.0364 \\
(0.063)\end{array}$ & & & $\begin{array}{c}0.2077^{* * *} \\
(0.024)\end{array}$ & & & $\begin{array}{c}0.1840^{* * *} \\
(0.043)\end{array}$ & & & $\begin{array}{c}-0.0223 \\
(0.047)\end{array}$ \\
\hline HP growth*Large*High capital & & & $\begin{array}{r}-0.0383 \\
(0.058)\end{array}$ & & & $\begin{array}{l}0.0221 \\
(0.023)\end{array}$ & & & $\begin{array}{c}0.0876^{* *} \\
(0.036)\end{array}$ & & & $\begin{array}{c}0.0824^{*} \\
(0.045)\end{array}$ \\
\hline HP growth*Small*Low capital & & & $\begin{array}{c}-0.0274 \\
(0.067)\end{array}$ & & & $\begin{array}{c}0.2050^{* * *} \\
(0.024)\end{array}$ & & & $\begin{array}{l}0.0673 \\
(0.045)\end{array}$ & & & $\begin{array}{l}0.0497 \\
(0.048)\end{array}$ \\
\hline Bank controls & Yes & Yes & Yes & Yes & Yes & Yes & Yes & Yes & Yes & Yes & Yes & Yes \\
\hline Observations & 99,377 & 99,377 & 99,125 & 109,257 & 109,257 & 108,994 & 101,145 & 101,145 & 100,910 & 85,380 & 85,380 & 85,250 \\
\hline R-squared & 0.224 & 0.224 & 0.224 & 0.403 & 0.404 & 0.406 & 0.381 & 0.381 & 0.381 & 0.366 & 0.367 & 0.367 \\
\hline Bank FE & Yes & Yes & Yes & Yes & Yes & Yes & Yes & Yes & Yes & Yes & Yes & Yes \\
\hline MSA*Year FE & Yes & Yes & Yes & Yes & Yes & Yes & Yes & Yes & Yes & Yes & Yes & Yes \\
\hline
\end{tabular}

Notes: The dependent variables are bank-level C\&I loan growth (columns 1-3), total asset growth (columns 4-6), real estate loan growth (columns 7-9), and liquid asset growth (columns 10-12). The regressions are run in a bank-level panel over 1977-2010. Bank size, capital, and total asset growth are at the bank level. All regressions include bank and MSA*year interacted fixed effects. All regressions include bank-level controls as in the baseline regressions (Table 2). Standard errors are clustered on bank. $* * *$ indicates statistical significance at the $1 \%$ level, ${ }^{* *}$ at the $5 \%$ level, and ${ }^{*}$ at the $10 \%$ level. 
Table 7: Corporate intangible capital and bank portfolio allocations - Ruling loan demand out as a possible channel (1)

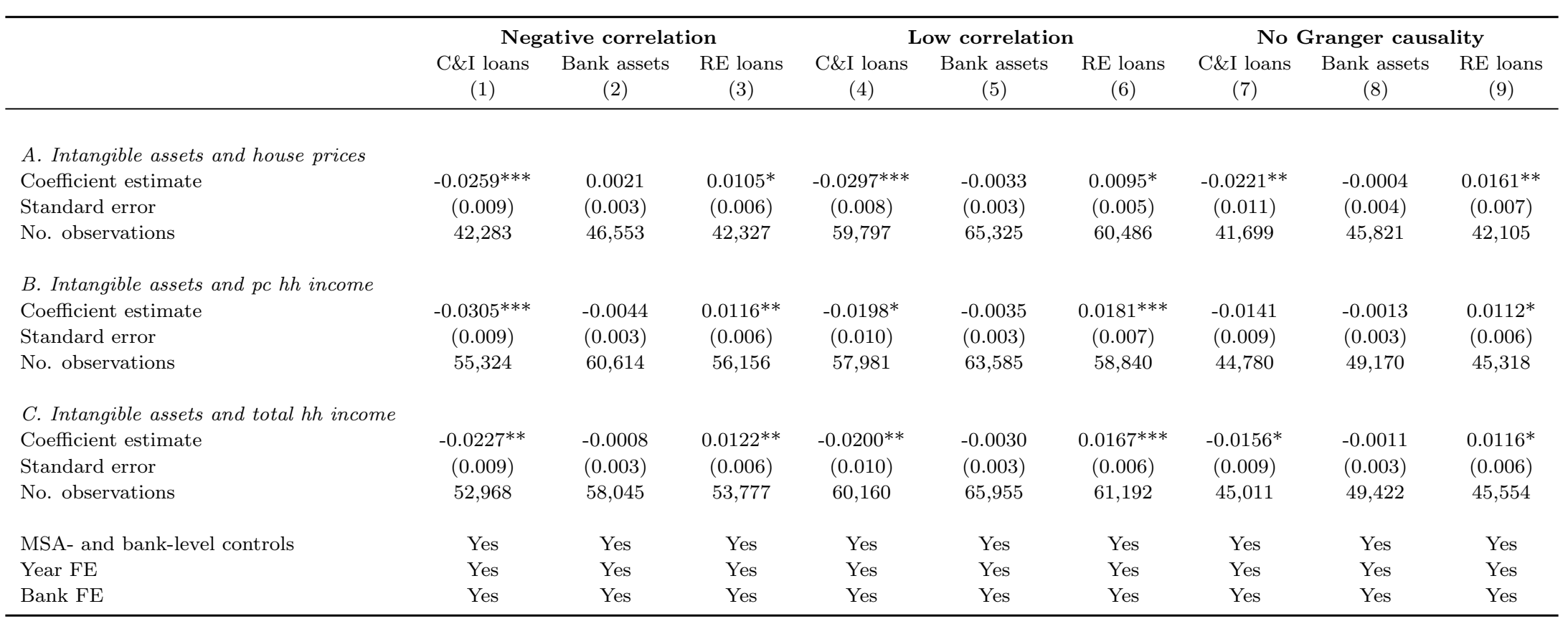

Notes: The dependent variables are bank-level C\&I loan growth, total asset growth, and real estate loan growth. The table reports the coefficient estimate on corporate intangible capital growth from regressions that restrict the sample to banks in the MSAs where the loan demand channel is likely to be weak, as reflected in a correlation between corporate intangible capital growth and the three macro variables that is either negative (columns 1-3), lower in absolute value than 25\% (columns 4-6) or does not indicate Granger causality from the macro variable to corporate intangible capital growth based on up to 2 lags (columns 7-9). The macro variables considered are house price growth (Panel A), per capita household income growth (Panel B), and total household income (Panel C). The regressions are run in a bank-level panel over 1977-2010. All regressions include the bank and MSA level control variables from the baseline specification (Table 2), as well as bank and year fixed effects. Standard errors are clustered on bank. *** indicates statistical significance at the $1 \%$ level, ** at the $5 \%$ level, and $*$ at the $10 \%$ level. 
Table 8: Corporate intangible capital and bank portfolio allocations-Ruling loan demand out as a possible channel (2)

\begin{tabular}{lcccccc}
\hline & \multicolumn{7}{c}{ No housing boom 2000-2007 } & \multicolumn{3}{c}{ No housing boom 1990-2007 } \\
& C\&I loans & Bank assets & RE loans & C\&I loans & Bank assets & RE loans \\
& $(1)$ & $(2)$ & $(3)$ & $(4)$ & $(5)$ & $(6)$ \\
\hline & & & & & & \\
A. HP increase below median & & & & & & \\
Coefficient estimate & $-0.0296^{* * *}$ & -0.0014 & 0.0098 & -0.0162 & 0.0026 & $0.0132^{*}$ \\
Standard error & $(0.010)$ & $(0.003)$ & $(0.006)$ & $(0.011)$ & $(0.003)$ & $(0.007)$ \\
No. observations & 44,801 & 49,453 & 45,823 & 47,541 & 52,233 & 48,715 \\
& & & & & & \\
B. HP increase below 75th percentile & & & & & & \\
Coefficient estimate & $-0.0328^{* * *}$ & 0.0006 & $0.0118^{* *}$ & $-0.0268^{* * *}$ & -0.0018 & 0.0073 \\
Standard error & $(0.008)$ & $(0.003)$ & $(0.005)$ & $(0.008)$ & $(0.003)$ & $(0.005)$ \\
No. observations & 64,487 & 70,873 & 65,453 & 61,318 & 67,285 & 62,421 \\
& & & & & & \\
C. HP increase below 90th percentile & & & & & \\
Coefficient estimate & $-0.0256^{* * *}$ & -0.0005 & $0.0128^{* *}$ & $-0.0250^{* * *}$ & -0.0005 & $0.0094^{*}$ \\
Standard error & $(0.008)$ & $(0.003)$ & $(0.005)$ & $(0.008)$ & $(0.003)$ & $(0.005)$ \\
No. observations & 72,662 & 79,716 & 73,719 & 73,500 & 80,718 & 74,513 \\
& & & & & & \\
MSA- and bank-level controls & Yes & Yes & Yes & Yes & Yes & Yes \\
Year FE & Yes & Yes & Yes & Yes & Yes & Yes \\
Bank FE & Yes & Yes & Yes & Yes & Yes & Yes \\
\hline
\end{tabular}

Notes: The dependent variables are bank-level C\&I loan growth, total asset growth, and real estate loan growth. The table reports the coefficient estimate on corporate intangible capital growth from regressions that restrict the sample to banks in the MSAs that did not experience a housing boom during 2000-2007 (columns 1-3) or 1990-2007 (columns 4-6). A housing boom is defined as the average rise of house prices over each period considered, in a given MSA, being above the sample median (Panel A) or in the top 75th percentile (Panel B). The regressions are run in a bank-level panel over 1977-2010. All regressions include the bank and MSA level control variables from the baseline specification (Table 2), as well as bank and year fixed effects. Standard errors are clustered on bank. $* * *$ indicates statistical significance at the $1 \%$ level, ${ }^{* *}$ at the $5 \%$ level, and $*$ at the $10 \%$ level. 
Table 9: Corporate intangible capital and bank profitability

\begin{tabular}{|c|c|c|c|}
\hline & \multicolumn{3}{|c|}{ Net interest margins } \\
\hline & (1) & $(2)$ & $(3)$ \\
\hline Intangible capital growth & $\begin{array}{c}-0.0142^{* * *} \\
(0.002)\end{array}$ & $\begin{array}{c}-0.0110^{* * *} \\
(0.002)\end{array}$ & $\begin{array}{c}-0.0036^{*} \\
(0.002)\end{array}$ \\
\hline House price growth & & $\begin{array}{c}0.1532^{* * *} \\
(0.007)\end{array}$ & $\begin{array}{c}0.1887^{* * *} \\
(0.009)\end{array}$ \\
\hline $\mathrm{Pc}$ income growth & & $\begin{array}{c}-0.0436^{* * *} \\
(0.013)\end{array}$ & $\begin{array}{c}0.0720^{* * *} \\
(0.018)\end{array}$ \\
\hline Population growth & & $\begin{array}{c}0.2859 * * * \\
(0.027)\end{array}$ & $\begin{array}{c}0.2632^{* * * *} \\
(0.055)\end{array}$ \\
\hline Firm sales growth & & $\begin{array}{l}-0.0009 \\
(0.002)\end{array}$ & $\begin{array}{l}0.0005 \\
(0.002)\end{array}$ \\
\hline Bank size & & $\begin{array}{c}0.0009 * * * \\
(0.000)\end{array}$ & $\begin{array}{l}-0.0013 \\
(0.001)\end{array}$ \\
\hline Bank capital & & $\begin{array}{c}0.0319 * * * \\
(0.006)\end{array}$ & $\begin{array}{c}0.0542^{* * *} \\
(0.014)\end{array}$ \\
\hline Bank asset growth & $\begin{array}{c}-0.2027^{* * *} \\
(0.004)\end{array}$ & $\begin{array}{c}-0.2232^{* * *} \\
(0.004)\end{array}$ & $\begin{array}{c}-0.3453^{* * *} \\
(0.005)\end{array}$ \\
\hline Observations & 75,920 & 75,920 & 75,920 \\
\hline R-squared & 0.048 & 0.060 & 0.248 \\
\hline Year FE & No & No & Yes \\
\hline Bank FE & No & No & Yes \\
\hline
\end{tabular}

Notes: The dependent variable is bank's net interest margins. The regressions are run in a bank-level panel over 1977-2010. Bank size, capital, and total asset growth are at the bank level. Standard errors are clustered on bank. ${ }^{* * *}$ indicates statistical significance at the $1 \%$ level, ${ }^{* *}$ at the $5 \%$ level, and $*$ at the $10 \%$ level. 
Table 10: Corporate intangible capital and bank portfolio allocations-Identification using interstate bank branching deregulation

\begin{tabular}{|c|c|c|c|c|c|c|c|c|}
\hline & \multicolumn{2}{|c|}{ C\&I loans } & \multicolumn{2}{|c|}{ Bank assets } & \multicolumn{2}{|c|}{ RE loans } & \multicolumn{2}{|c|}{ Liquid assets } \\
\hline & (1) & (2) & (3) & (4) & (5) & (6) & (7) & (8) \\
\hline IK growth*Regulated & $\begin{array}{c}-0.0444^{* * *} \\
(0.016)\end{array}$ & $\begin{array}{c}-0.0308^{*} \\
(0.016)\end{array}$ & $\begin{array}{c}-0.0008 \\
(0.005)\end{array}$ & $\begin{array}{l}0.0005 \\
(0.006)\end{array}$ & $\begin{array}{c}0.0604^{* * *} \\
(0.012)\end{array}$ & $\begin{array}{c}0.0429^{* * *} \\
(0.012)\end{array}$ & $\begin{array}{c}-0.0041 \\
(0.013)\end{array}$ & $\begin{array}{c}-0.0068 \\
(0.013)\end{array}$ \\
\hline IK growth & $\begin{array}{c}0.0140^{* *} \\
(0.007)\end{array}$ & $\begin{array}{l}-0.0130 \\
(0.008)\end{array}$ & $\begin{array}{c}-0.0151^{* * *} \\
(0.002)\end{array}$ & $\begin{array}{c}-0.0255^{* * *} \\
(0.003)\end{array}$ & $\begin{array}{l}-0.0080 \\
(0.005)\end{array}$ & $\begin{array}{c}-0.0098 \\
(0.006)\end{array}$ & $\begin{array}{c}-0.0050 \\
(0.006)\end{array}$ & $\begin{array}{l}0.0058 \\
(0.006)\end{array}$ \\
\hline HP growth*Regulated & $\begin{array}{c}-0.0128^{*} \\
(0.007)\end{array}$ & $\begin{array}{c}-0.0139^{*} \\
(0.007)\end{array}$ & $\begin{array}{l}0.0017 \\
(0.002)\end{array}$ & $\begin{array}{l}0.0020 \\
(0.002)\end{array}$ & $\begin{array}{r}-0.0032 \\
(0.004)\end{array}$ & $\begin{array}{l}0.0002 \\
(0.004)\end{array}$ & $\begin{array}{c}0.0156^{* * * *} \\
(0.005)\end{array}$ & $\begin{array}{c}0.0156^{* * *} \\
(0.005)\end{array}$ \\
\hline Pc income growth*Regulated & & $\begin{array}{c}0.1127^{* * *} \\
(0.035)\end{array}$ & & $\begin{array}{l}0.0177^{*} \\
(0.011)\end{array}$ & & $\begin{array}{c}-0.0412^{*} \\
(0.024)\end{array}$ & & $\begin{array}{c}-0.0502^{* *} \\
(0.024)\end{array}$ \\
\hline Population growth*Regulated & & $\begin{array}{c}0.3506^{* * *} \\
(0.066)\end{array}$ & & $\begin{array}{c}0.0875^{* * *} \\
(0.023)\end{array}$ & & $\begin{array}{c}-0.0826 \\
(0.055)\end{array}$ & & $\begin{array}{c}-0.0947^{*} \\
(0.052)\end{array}$ \\
\hline Firm sales growth*Regulated & & $\begin{array}{l}0.1678 \\
(0.133)\end{array}$ & & $\begin{array}{c}0.3943^{* * *} \\
(0.051)\end{array}$ & & $\begin{array}{c}1.1593^{* * *} \\
(0.108)\end{array}$ & & $\begin{array}{c}-0.2311^{* *} \\
(0.111)\end{array}$ \\
\hline Regulated & & $\begin{array}{l}0.0237 \\
(0.017)\end{array}$ & & $\begin{array}{c}0.0101^{*} \\
(0.005)\end{array}$ & & $\begin{array}{c}-0.0325^{* *} \\
(0.013)\end{array}$ & & $\begin{array}{c}-0.0146 \\
(0.014)\end{array}$ \\
\hline Bank and MSA-level controls & Yes & Yes & Yes & Yes & Yes & Yes & Yes & Yes \\
\hline Observations & 62,430 & 62,430 & 68,474 & 68,474 & 62,837 & 62,837 & 53,136 & 53,136 \\
\hline R-squared & 0.182 & 0.183 & 0.339 & 0.341 & 0.315 & 0.317 & 0.301 & 0.301 \\
\hline
\end{tabular}

Notes: The dependent variable is bank-level C\&I loan growth (columns 1-2), total asset growth (columns 3-4), real estate loan growth (columns 5-6), and liquid asset growth (columns 7-82). The regressions are run in a bank-level panel over 1977-2010. Regulated takes value 1 for states in the years before interstate bank branching deregulation. The sample is restricted to banks in the MSAs that are contained within one state. All regressions include bank and year fixed effects, as well as bank level controls and all the macro variables from the baseline specifications (Table 2). The regressions are run in a bank-level panel over 1977-2010. Standard errors are clustered on bank. *** indicates statistical significance at the $1 \%$ level, ${ }^{* *}$ at the $5 \%$ level, and $*$ at the $10 \%$ level. 


\section{Appendix}

Figure A1: Variable definitions and sources

\begin{tabular}{|c|c|c|}
\hline \multirow[b]{3}{*}{ Firm variables } & \multicolumn{2}{|l|}{ Variable definitions } \\
\hline & Definition & Data source \\
\hline & & \\
\hline Intangible capital & $\begin{array}{l}\text { Capitalized past expenditures on R\&D, SG\&A, and computerized information } \\
\text { and software (IT) }\end{array}$ & $\begin{array}{l}\text { Falato, Kadyrzhanova and Sim (2013) } \\
\text { based on Compustat }\end{array}$ \\
\hline $\begin{array}{l}\text { Firms' sales } \\
\text { Bank variables }\end{array}$ & Total firm sales & Compustat \\
\hline C\&I loans & $\begin{array}{l}\text { Commercial and industrial loans, in US\$ or divided by total assets. For years } \\
\text { 1976-2000, we use RCON1600 divided by RCON2170. For years 2001-2010, } \\
\text { we use (RCON1755+RCON1766) divided by RCON2170. If RCON1755 is } \\
\text { missing, we use RCON1766 instead. }\end{array}$ & $\begin{array}{l}\text { US Call Reports, Chicago Fed website } \\
\text { https://www.chicagofed.org/banking/t } \\
\text { inancial-institution- } \\
\text { reports/commercial-bank-data }\end{array}$ \\
\hline Real estate loans & $\begin{array}{l}\text { RCON1410. Split into residential real estate loans (RCON1430+RCON1460) } \\
\text { and commercial real estate loans (the difference between total and } \\
\text { residential real estate loans) }\end{array}$ & US Call Reports \\
\hline Liquid assets & $\begin{array}{l}\text { Summation of cash (RCON0010), government securities (RCON0040 + } \\
\text { RCON0600+RCON0900 before 1984; RCON0400+RCON0600+RCON0402 } \\
\text { between 1983-1994; and RCON0211+RCON1286+RCON1289+RCON1291+ } \\
\text { +RCON1294+RCON1297+RCON8496+RCON8498 after 1993), net interbank } \\
\text { position (assets - liabilities in federal funds market, i.e. RCON1350-RCON2800 } \\
\text { before 2002; and RCON987+RCONB989-RCONB993-RCONB995 after 2002) } \\
\text { and mortgage backed securities (RCON8639 before 2009 and } \\
\text { RCONG857+RCONG860 after 2008) }\end{array}$ & US Call Reports \\
\hline Bank size & Log of total bank assets (RCON2170) & US Call Reports \\
\hline $\begin{array}{l}\text { Bank capital } \\
\text { Macro variables }\end{array}$ & Total equity (RCON3210) divided by total assets (RCON2170) & \\
\hline House price index & All transactions seasonally-adjusted house price index at the MSA level & $\begin{array}{l}\text { Federal Housing Finance Agency } \\
\text { website } \\
\text { http://www.fhfa.gov/DataTools/Down }\end{array}$ \\
\hline $\begin{array}{l}\text { Per capita household } \\
\text { income }\end{array}$ & Per capital household income at the MSA level & $\begin{array}{l}\text { Bureau of Economic Analysis Loan } \\
\text { Area Personal Income accounts, } \\
\text { website } \\
\text { http://www.bea.gov/regional/downlo } \\
\text { adzip.cfm }\end{array}$ \\
\hline Population & Total MSA-level population & $\begin{array}{l}\text { Bureau of Economic Analysis Loan } \\
\text { Area Personal Income accounts, } \\
\text { website } \\
\text { http://www.bea.gov/regional/downlo } \\
\text { adzip.cfm }\end{array}$ \\
\hline Regulated & $\begin{array}{l}\text { Indicator for single-state MSAs until the year of interstate bank branching } \\
\text { deregulation }\end{array}$ & Michalski and Ors (2012) \\
\hline
\end{tabular}


Table A1: Corporate intangible capital and bank portfolio allocations - Components of intangible capital

\begin{tabular}{|c|c|c|c|c|c|c|c|c|c|c|c|c|}
\hline & \multicolumn{4}{|c|}{ Exclude IT } & \multicolumn{4}{|c|}{ R\&D } & \multicolumn{4}{|c|}{ SG\&A } \\
\hline & $\begin{array}{c}\text { C\&I loans } \\
(1)\end{array}$ & $\begin{array}{c}\text { Bank assets } \\
(2)\end{array}$ & $\begin{array}{c}\text { RE loans } \\
\text { (3) }\end{array}$ & $\begin{array}{l}\text { Liquid } \\
\text { assets } \\
(4)\end{array}$ & $\begin{array}{c}\text { C\&I loans } \\
(5)\end{array}$ & $\begin{array}{c}\text { Bank assets } \\
\text { (6) }\end{array}$ & $\begin{array}{c}\text { RE loans } \\
\text { (7) }\end{array}$ & $\begin{array}{l}\text { Liquid } \\
\text { assets } \\
(8)\end{array}$ & $\begin{array}{c}\text { C\&I loans } \\
\text { (9) }\end{array}$ & $\begin{array}{c}\text { Bank assets } \\
\text { (10) }\end{array}$ & $\begin{array}{c}\text { RE loans } \\
\text { (11) }\end{array}$ & $\begin{array}{l}\text { Liquid } \\
\text { assets } \\
(12)\end{array}$ \\
\hline IK growth & $\begin{array}{c}-0.0192^{* * *} \\
(0.006)\end{array}$ & $\begin{array}{l}0.0005 \\
(0.002)\end{array}$ & $\begin{array}{c}0.0119^{* * *} \\
(0.004)\end{array}$ & $\begin{array}{c}0.0093^{* *} \\
(0.004)\end{array}$ & $\begin{array}{c}-0.0122^{* *} \\
(0.005)\end{array}$ & $\begin{array}{l}0.0001 \\
(0.002)\end{array}$ & $\begin{array}{l}0.0045 \\
(0.003)\end{array}$ & $\begin{array}{l}-0.0018 \\
(0.004)\end{array}$ & $\begin{array}{c}-0.0180^{* * * *} \\
(0.006)\end{array}$ & $\begin{array}{l}0.0003 \\
(0.002)\end{array}$ & $\begin{array}{c}0.0123^{* * *} \\
(0.004)\end{array}$ & $\begin{array}{l}0.0082^{*} \\
(0.004)\end{array}$ \\
\hline HP growth & $\begin{array}{c}0.1073^{* * *} \\
(0.018)\end{array}$ & $\begin{array}{c}0.1469^{* * *} \\
(0.006)\end{array}$ & $\begin{array}{c}0.2125^{* * *} \\
(0.013)\end{array}$ & $\begin{array}{c}-0.2163^{* * *} \\
(0.014)\end{array}$ & $\begin{array}{c}0.1107^{* * *} \\
(0.019)\end{array}$ & $\begin{array}{c}0.1450^{* * *} \\
(0.007)\end{array}$ & $\begin{array}{c}0.2130^{* * *} \\
(0.013)\end{array}$ & $\begin{array}{c}-0.2134^{* * * *} \\
(0.015)\end{array}$ & $\begin{array}{c}0.1076^{* * *} \\
(0.018)\end{array}$ & $\begin{array}{c}0.1468^{* * *} \\
(0.006)\end{array}$ & $\begin{array}{c}0.2125^{* * *} \\
(0.013)\end{array}$ & $\begin{array}{c}-0.2165^{* * *} \\
(0.014)\end{array}$ \\
\hline Pc income growth & $\begin{array}{c}0.1955^{* * *} \\
(0.036)\end{array}$ & $\begin{array}{c}0.1912^{* * *} \\
(0.013)\end{array}$ & $\begin{array}{l}0.0315 \\
(0.027)\end{array}$ & $\begin{array}{r}-0.0008 \\
(0.028)\end{array}$ & $\begin{array}{c}0.2077^{* * *} \\
(0.043)\end{array}$ & $\begin{array}{c}0.2319^{* * *} \\
(0.014)\end{array}$ & $\begin{array}{c}0.0554^{*} \\
(0.031)\end{array}$ & $\begin{array}{l}0.0039 \\
(0.033)\end{array}$ & $\begin{array}{c}0.1952^{* * *} \\
(0.036)\end{array}$ & $\begin{array}{c}0.1912^{* * *} \\
(0.013)\end{array}$ & $\begin{array}{l}0.0318 \\
(0.027)\end{array}$ & $\begin{array}{l}-0.0006 \\
(0.028)\end{array}$ \\
\hline Population growth & $\begin{array}{c}0.6905^{* * *} \\
(0.101)\end{array}$ & $\begin{array}{c}0.7391^{* * *} \\
(0.038)\end{array}$ & $\begin{array}{c}1.8830^{* * *} \\
(0.088)\end{array}$ & $\begin{array}{c}-1.0019 * * * \\
(0.078)\end{array}$ & $\begin{array}{c}0.6730^{* * *} \\
(0.107)\end{array}$ & $\begin{array}{c}0.7453^{* * *} \\
(0.040)\end{array}$ & $\begin{array}{c}1.9132^{* * *} \\
(0.093)\end{array}$ & $\begin{array}{c}-0.9853^{* * *} \\
(0.083)\end{array}$ & $\begin{array}{c}0.6901^{* * * *} \\
(0.101)\end{array}$ & $\begin{array}{c}0.7392^{* * *} \\
(0.038)\end{array}$ & $\begin{array}{c}1.8829^{* * *} \\
(0.088)\end{array}$ & $\begin{array}{c}-1.0013^{* * *} \\
(0.078)\end{array}$ \\
\hline Firm sales growth & $\begin{array}{c}0.0119^{*} \\
(0.006)\end{array}$ & $\begin{array}{c}0.0095^{* * *} \\
(0.002)\end{array}$ & $\begin{array}{l}0.0053 \\
(0.004)\end{array}$ & $\begin{array}{l}0.0012 \\
(0.005)\end{array}$ & $\begin{array}{c}0.0254^{* * *} \\
(0.008)\end{array}$ & $\begin{array}{c}0.0071^{* * *} \\
(0.003)\end{array}$ & $\begin{array}{l}0.0027 \\
(0.005)\end{array}$ & $\begin{array}{c}-0.0131^{* *} \\
(0.006)\end{array}$ & $\begin{array}{c}0.0122^{* *} \\
(0.006)\end{array}$ & $\begin{array}{c}0.0095^{* * *} \\
(0.002)\end{array}$ & $\begin{array}{l}0.0053 \\
(0.004)\end{array}$ & $\begin{array}{l}0.0010 \\
(0.005)\end{array}$ \\
\hline Bank size & $\begin{array}{c}-0.0129^{* * * *} \\
(0.003)\end{array}$ & $\begin{array}{c}-0.0285^{* * *} \\
(0.001)\end{array}$ & $\begin{array}{c}-0.0096^{* * *} \\
(0.002)\end{array}$ & $\begin{array}{l}0.0009 \\
(0.002)\end{array}$ & $\begin{array}{c}-0.0122^{* * *} \\
(0.003)\end{array}$ & $\begin{array}{c}-0.0283^{* * *} \\
(0.001)\end{array}$ & $\begin{array}{c}-0.0104^{* * *} \\
(0.002)\end{array}$ & $\begin{array}{l}0.0012 \\
(0.002)\end{array}$ & $\begin{array}{c}-0.0129^{* * * *} \\
(0.003)\end{array}$ & $\begin{array}{c}-0.0285^{* * *} \\
(0.001)\end{array}$ & $\begin{array}{c}-0.0096^{* * *} \\
(0.002)\end{array}$ & $\begin{array}{l}0.0010 \\
(0.002)\end{array}$ \\
\hline Bank capital & $\begin{array}{c}0.1171^{* * *} \\
(0.032)\end{array}$ & $\begin{array}{c}0.1588^{* * *} \\
(0.015)\end{array}$ & $\begin{array}{c}0.0713^{* * *} \\
(0.021)\end{array}$ & $\begin{array}{c}-0.1035^{* * * *} \\
(0.025)\end{array}$ & $\begin{array}{c}0.1135^{* * *} \\
(0.034)\end{array}$ & $\begin{array}{c}0.1558^{* * * *} \\
(0.016)\end{array}$ & $\begin{array}{c}0.0700^{* * *} \\
(0.022)\end{array}$ & $\begin{array}{c}-0.1060^{* * *} \\
(0.026)\end{array}$ & $\begin{array}{c}0.1170^{* * * *} \\
(0.032)\end{array}$ & $\begin{array}{c}0.1588^{* * *} \\
(0.015)\end{array}$ & $\begin{array}{c}0.0713^{* * *} \\
(0.021)\end{array}$ & $\begin{array}{c}-0.1035^{* * *} \\
(0.025)\end{array}$ \\
\hline Bank asset growth & $\begin{array}{c}0.6107^{* * *} \\
(0.011)\end{array}$ & & $\begin{array}{c}0.5803^{* * *} \\
(0.008)\end{array}$ & $\begin{array}{c}0.9867^{* * *} \\
(0.010)\end{array}$ & $\begin{array}{c}0.6107^{* * *} \\
(0.012)\end{array}$ & & $\begin{array}{c}0.5788^{* * *} \\
(0.008)\end{array}$ & $\begin{array}{c}0.9822^{* * *} \\
(0.011)\end{array}$ & $\begin{array}{c}0.6107^{* * *} \\
(0.011)\end{array}$ & & $\begin{array}{c}0.5803^{* * *} \\
(0.008)\end{array}$ & $\begin{array}{c}0.9867^{* * *} \\
(0.010)\end{array}$ \\
\hline Observations & 99,890 & 109,710 & 101,623 & 86,057 & 93,040 & 102,340 & 94,671 & 80,155 & 99,890 & 109,710 & 101,623 & 86,057 \\
\hline R-squared & 0.168 & 0.339 & 0.318 & 0.293 & 0.167 & 0.340 & 0.319 & 0.294 & 0.168 & 0.339 & 0.318 & 0.293 \\
\hline Year FE & Yes & Yes & Yes & Yes & Yes & Yes & Yes & Yes & Yes & Yes & Yes & Yes \\
\hline Bank FE & Yes & Yes & Yes & Yes & Yes & Yes & Yes & Yes & Yes & Yes & Yes & Yes \\
\hline
\end{tabular}

Notes: This table explores the robustness of the results to alternative definitions of intangible capital. The dependent variables are bank-level C\&I loan growth, total asset growth, real estate loan growth, and liquid asset growth. In columns 1-4 the definition of intangible capital excludes IT expenditure; in columns $5-8$ it only considers the R\&D component of total intangible capital, and in columns 9-12 it focuses on the SG\&A component. The regressions are run in a bank-level panel over 1977-2010. Standard errors are clustered on bank. ${ }^{* * *}$ indicates statistical significance at the $1 \%$ level, ${ }^{* *}$ at the $5 \%$ level, and $*$ at the $10 \%$ level. 
Table A2: Corporate intangible capital and bank portfolio allocations-Additional controls

\begin{tabular}{|c|c|c|c|c|c|c|c|c|c|c|c|c|}
\hline & \multicolumn{4}{|c|}{ Control for \% of rated firms } & \multicolumn{4}{|c|}{ Control for \# of patents } & \multicolumn{4}{|c|}{ Control for \# of citation-weighted patents } \\
\hline & $\begin{array}{c}\text { C\&I loans } \\
(1)\end{array}$ & $\begin{array}{c}\text { Bank assets } \\
\text { (2) }\end{array}$ & $\begin{array}{c}\text { RE loans } \\
\text { (3) }\end{array}$ & $\begin{array}{l}\text { Liquid } \\
\text { assets } \\
(4)\end{array}$ & $\begin{array}{c}\text { C\&I loans } \\
(5)\end{array}$ & $\begin{array}{c}\text { Bank assets } \\
\text { (6) }\end{array}$ & $\begin{array}{l}\text { RE loans } \\
\text { (7) }\end{array}$ & $\begin{array}{l}\text { Liquid } \\
\text { assets } \\
(8)\end{array}$ & $\begin{array}{c}\text { C\&I loans } \\
\text { (9) }\end{array}$ & $\begin{array}{c}\text { Bank assets } \\
\text { (10) }\end{array}$ & $\begin{array}{l}\text { RE loans } \\
\text { (11) }\end{array}$ & $\begin{array}{l}\text { Liquid } \\
\text { assets } \\
(12)\end{array}$ \\
\hline IK growth & $\begin{array}{c}-0.0197^{* * *} \\
(0.006)\end{array}$ & $\begin{array}{l}0.0006 \\
(0.002)\end{array}$ & $\begin{array}{c}0.0133^{* * *} \\
(0.004)\end{array}$ & $\begin{array}{c}0.0089^{*} \\
(0.005)\end{array}$ & $\begin{array}{c}-0.0415^{* * *} \\
(0.012)\end{array}$ & $\begin{array}{r}-0.0056 \\
(0.004)\end{array}$ & $\begin{array}{c}0.0288^{* * *} \\
(0.007)\end{array}$ & $\begin{array}{l}0.0068 \\
(0.008)\end{array}$ & $\begin{array}{c}-0.0420^{* * *} \\
(0.012)\end{array}$ & $\begin{array}{r}-0.0057 \\
(0.004)\end{array}$ & $\begin{array}{c}0.0279^{* * *} \\
(0.007)\end{array}$ & $\begin{array}{l}0.0077 \\
(0.008)\end{array}$ \\
\hline HP growth & $\begin{array}{c}0.1067^{* * *} \\
(0.018)\end{array}$ & $\begin{array}{c}0.1465^{* * *} \\
(0.006)\end{array}$ & $\begin{array}{c}0.2120^{* * *} \\
(0.013)\end{array}$ & $\begin{array}{c}-0.2161^{* * * *} \\
(0.014)\end{array}$ & $\begin{array}{c}0.1319^{* * *} \\
(0.023)\end{array}$ & $\begin{array}{c}0.1417^{* * *} \\
(0.008)\end{array}$ & $\begin{array}{c}0.2281^{* * *} \\
(0.016)\end{array}$ & $\begin{array}{c}-0.2277^{* * *} \\
(0.017)\end{array}$ & $\begin{array}{c}0.1317^{* * *} \\
(0.023)\end{array}$ & $\begin{array}{c}0.1416^{* * *} \\
(0.008)\end{array}$ & $\begin{array}{c}0.2282^{* * *} \\
(0.016)\end{array}$ & $\begin{array}{c}-0.2278^{* * *} \\
(0.017)\end{array}$ \\
\hline Pc income growth & $\begin{array}{c}0.1941^{* * * *} \\
(0.036)\end{array}$ & $\begin{array}{c}0.1903^{* * *} \\
(0.013)\end{array}$ & $\begin{array}{l}0.0299 \\
(0.027)\end{array}$ & $\begin{array}{l}0.0010 \\
(0.028)\end{array}$ & $\begin{array}{c}0.2261^{* * * *} \\
(0.050)\end{array}$ & $\begin{array}{c}0.2480^{* * *} \\
(0.016)\end{array}$ & $\begin{array}{c}-0.0083 \\
(0.034)\end{array}$ & $\begin{array}{l}0.0272 \\
(0.037)\end{array}$ & $\begin{array}{c}0.2258^{* * *} \\
(0.050)\end{array}$ & $\begin{array}{c}0.2480^{* * *} \\
(0.016)\end{array}$ & $\begin{array}{r}-0.0091 \\
(0.034)\end{array}$ & $\begin{array}{l}0.0274 \\
(0.037)\end{array}$ \\
\hline Population growth & $\begin{array}{c}0.6794^{* * *} \\
(0.101)\end{array}$ & $\begin{array}{c}0.7324^{* * *} \\
(0.038)\end{array}$ & $\begin{array}{c}1.8716^{* * *} \\
(0.088)\end{array}$ & $\begin{array}{c}-0.9918^{* * * *} \\
(0.078)\end{array}$ & $\begin{array}{c}0.5993^{* * *} \\
(0.131)\end{array}$ & $\begin{array}{c}0.8442^{* * *} \\
(0.046)\end{array}$ & $\begin{array}{c}2.3029^{* * *} \\
(0.092)\end{array}$ & $\begin{array}{c}-1.0977^{* * *} \\
(0.092)\end{array}$ & $\begin{array}{c}0.6011^{* * *} \\
(0.131)\end{array}$ & $\begin{array}{c}0.8446^{* * *} \\
(0.046)\end{array}$ & $\begin{array}{c}2.3058^{* * *} \\
(0.092)\end{array}$ & $\begin{array}{c}-1.0999^{* * * *} \\
(0.092)\end{array}$ \\
\hline Firm sales growth & $\begin{array}{c}0.0119^{*} \\
(0.006)\end{array}$ & $\begin{array}{c}0.0096^{* * *} \\
(0.002)\end{array}$ & $\begin{array}{l}0.0057 \\
(0.004)\end{array}$ & $\begin{array}{l}0.0011 \\
(0.005)\end{array}$ & $\begin{array}{c}0.0525^{* * *} \\
(0.012)\end{array}$ & $\begin{array}{c}0.0100^{* * * *} \\
(0.004)\end{array}$ & $\begin{array}{l}0.0139^{*} \\
(0.008)\end{array}$ & $\begin{array}{c}-0.0286^{* * *} \\
(0.009)\end{array}$ & $\begin{array}{c}0.0527^{* * * *} \\
(0.012)\end{array}$ & $\begin{array}{c}0.0101^{* * *} \\
(0.004)\end{array}$ & $\begin{array}{l}0.0144^{*} \\
(0.008)\end{array}$ & $\begin{array}{c}-0.0290^{* * *} \\
(0.009)\end{array}$ \\
\hline Bank size & $\begin{array}{c}-0.0127^{* * *} \\
(0.003)\end{array}$ & $\begin{array}{c}-0.0284^{* * *} \\
(0.001)\end{array}$ & $\begin{array}{c}-0.0094^{* * *} \\
(0.002)\end{array}$ & $\begin{array}{l}0.0008 \\
(0.002)\end{array}$ & $\begin{array}{c}-0.0111^{* * * *} \\
(0.003)\end{array}$ & $\begin{array}{c}-0.0251^{* * *} \\
(0.002)\end{array}$ & $\begin{array}{c}-0.0088^{* * *} \\
(0.002)\end{array}$ & $\begin{array}{c}-0.0038^{*} \\
(0.002)\end{array}$ & $\begin{array}{c}-0.0111^{* * * *} \\
(0.003)\end{array}$ & $\begin{array}{c}-0.0251^{* * * *} \\
(0.002)\end{array}$ & $\begin{array}{c}-0.0089^{* * * *} \\
(0.002)\end{array}$ & $\begin{array}{c}-0.0038^{*} \\
(0.002)\end{array}$ \\
\hline Bank capital & $\begin{array}{c}0.1170^{* * *} \\
(0.032)\end{array}$ & $\begin{array}{c}0.1588^{* * * *} \\
(0.015)\end{array}$ & $\begin{array}{c}0.0714^{* * *} \\
(0.021)\end{array}$ & $\begin{array}{c}-0.1035^{* * * *} \\
(0.025)\end{array}$ & $\begin{array}{c}0.1434^{* * *} \\
(0.042)\end{array}$ & $\begin{array}{c}0.1594^{* * *} \\
(0.019)\end{array}$ & $\begin{array}{c}0.0594^{* *} \\
(0.028)\end{array}$ & $\begin{array}{c}-0.1184^{* * *} \\
(0.031)\end{array}$ & $\begin{array}{c}0.1435^{* * *} \\
(0.042)\end{array}$ & $\begin{array}{c}0.1594^{* * *} \\
(0.019)\end{array}$ & $\begin{array}{c}0.0596^{* *} \\
(0.028)\end{array}$ & $\begin{array}{c}-0.1185^{* * *} \\
(0.031)\end{array}$ \\
\hline Bank asset growth & $\begin{array}{c}0.6105^{* * *} \\
(0.011)\end{array}$ & & $\begin{array}{c}0.5800^{* * *} \\
(0.008)\end{array}$ & $\begin{array}{c}0.9869^{* * *} \\
(0.010)\end{array}$ & $\begin{array}{c}0.6063^{* * *} \\
(0.013)\end{array}$ & & $\begin{array}{c}0.5554^{* * *} \\
(0.009)\end{array}$ & $\begin{array}{c}0.9980^{* * *} \\
(0.012)\end{array}$ & $\begin{array}{c}0.6063^{* * *} \\
(0.013)\end{array}$ & & $\begin{array}{c}0.5554^{* * *} \\
(0.009)\end{array}$ & $\begin{array}{c}0.9980^{* * *} \\
(0.012)\end{array}$ \\
\hline$\%$ rated firms & $\begin{array}{c}0.0154^{* *} \\
(0.007)\end{array}$ & $\begin{array}{c}0.0086^{* * *} \\
(0.003)\end{array}$ & $\begin{array}{c}0.0136^{* * *} \\
(0.005)\end{array}$ & $\begin{array}{c}-0.0106^{* *} \\
(0.005)\end{array}$ & $\begin{array}{l}0.0014 \\
(0.002)\end{array}$ & & & & & & & \\
\hline \# patents & & & & & & $\begin{array}{l}0.0003 \\
(0.001)\end{array}$ & $\begin{array}{c}-0.0022^{*} \\
(0.001)\end{array}$ & $\begin{array}{c}0.0027^{*} \\
(0.001)\end{array}$ & $\begin{array}{l}0.0020 \\
(0.001)\end{array}$ & $\begin{array}{l}0.0004 \\
(0.000)\end{array}$ & $\begin{array}{l}0.0001 \\
(0.001)\end{array}$ & $\begin{array}{l}0.0008 \\
(0.001)\end{array}$ \\
\hline Observations & 99,890 & 109,710 & 101,623 & 86,057 & 75,953 & 83,739 & 77,061 & 65,876 & 75,953 & 83,739 & 77,061 & 65,876 \\
\hline R-squared & 0.168 & 0.339 & 0.318 & 0.293 & 0.169 & 0.358 & 0.320 & 0.304 & 0.169 & 0.358 & 0.320 & 0.304 \\
\hline Year FE & Yes & Yes & Yes & Yes & Yes & Yes & Yes & Yes & Yes & Yes & Yes & Yes \\
\hline Bank FE & Yes & Yes & Yes & Yes & Yes & Yes & Yes & Yes & Yes & Yes & Yes & Yes \\
\hline
\end{tabular}

Notes: This table explores the robustness of the results to additional controls. The dependent variables are bank-level C\&I loan growth, total asset growth, real estate loan growth, and liquid asset growth. In columns 1-4 we add the MSA-level share of firms with an S\&P rating; in columns 5-12 we add the MSA-level number of patents (simple summation in columns 5-8 and citation-weighted in columns 9-12). The regressions are run in a bank-level panel over 1977-2010. Standard errors are clustered on bank. $* * *$ indicates statistical significance at the $1 \%$ level, $* *$ at the $5 \%$ level, and * at the $10 \%$ level. 
Table A3: Corporate intangible capital and bank portfolio allocations-Alternative approaches

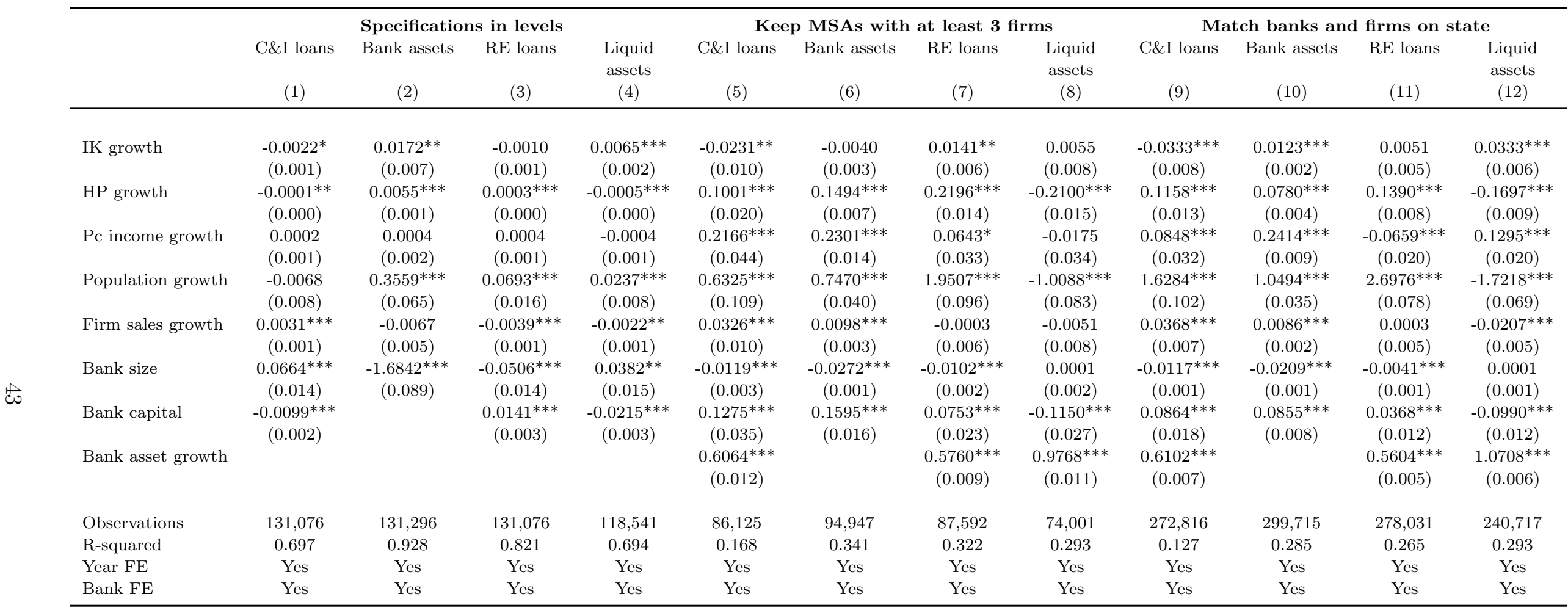

Notes: This table explores the robustness of the results to additional tests. The dependent variables are bank-level C\&I loan growth, total asset growth, real estate loan growth, and liquid asset growth in all columns other than 1-4, where they are C\&I loans (as a share of total loans), bank size (log-total assets), real estate loans (as a share of total loans), and liquid assets (as a share of total assets). In columns 1-4 the explanatory variables are also in levels (per capita income, population, and firm sales are log-transformed). In the remaining columns we revert to the usual specification in growth rates. In columns 5-8 we limit the sample to the banks in MSAs for which intangible capital is computed based on at least three Compustat firms. In columns 9-12 we match banks and firms on state (rather than MSA) and all macro controls are at the state (rather than MSA) level. The regressions are run in a bank-level panel over 1977-2010. Standard errors are clustered on bank. *** indicates statistical significance at the $1 \%$ level, $* *$ at the $5 \%$ level, and * at the $10 \%$ level. 
Table A4: Corporate intangible capital and bank portfolio allocations-Alternative clustering

\begin{tabular}{|c|c|c|c|c|c|c|c|c|c|c|c|c|}
\hline & \multicolumn{4}{|c|}{ Double cluster on bank and year } & \multicolumn{4}{|c|}{ Cluster on MSA } & \multicolumn{4}{|c|}{ Double cluster on MSA and year } \\
\hline & $\begin{array}{c}\text { C\&I loans } \\
\text { (1) }\end{array}$ & $\begin{array}{c}\text { Bank assets } \\
\text { (2) }\end{array}$ & $\begin{array}{c}\text { RE loans } \\
\text { (3) }\end{array}$ & $\begin{array}{l}\text { Liquid } \\
\text { assets } \\
(4)\end{array}$ & $\begin{array}{c}\text { C\&I loans } \\
(5)\end{array}$ & $\begin{array}{c}\text { Bank assets } \\
\text { (6) }\end{array}$ & $\begin{array}{l}\text { RE loans } \\
\quad(7)\end{array}$ & $\begin{array}{l}\text { Liquid } \\
\text { assets } \\
(8)\end{array}$ & $\begin{array}{c}\text { C\&I loans } \\
\text { (9) }\end{array}$ & $\begin{array}{c}\text { Bank assets } \\
\text { (10) }\end{array}$ & $\begin{array}{l}\text { RE loans } \\
\text { (11) }\end{array}$ & $\begin{array}{l}\text { Liquid } \\
\text { assets } \\
(12)\end{array}$ \\
\hline IK growth & $\begin{array}{c}-0.0204^{* *} \\
(0.008)\end{array}$ & $\begin{array}{l}0.0002 \\
(0.003)\end{array}$ & $\begin{array}{c}0.0127^{* *} \\
(0.005)\end{array}$ & $\begin{array}{c}0.0092 \# \\
(0.007)\end{array}$ & $\begin{array}{c}-0.0204^{* *} \\
(0.009)\end{array}$ & $\begin{array}{l}0.0002 \\
(0.003)\end{array}$ & $\begin{array}{c}0.0127^{* *} \\
(0.006)\end{array}$ & $\begin{array}{c}0.0092 \# \\
(0.007)\end{array}$ & $\begin{array}{c}-0.0204^{* *} \\
(0.010)\end{array}$ & $\begin{array}{l}0.0002 \\
(0.004)\end{array}$ & $\begin{array}{c}0.0127^{* *} \\
(0.006)\end{array}$ & $\begin{array}{c}0.0092 \# \\
(0.008)\end{array}$ \\
\hline HP growth & $\begin{array}{c}0.1073^{* * *} \\
(0.030)\end{array}$ & $\begin{array}{c}0.1468^{* * *} \\
(0.022)\end{array}$ & $\begin{array}{c}0.2125^{* * *} \\
(0.051)\end{array}$ & $\begin{array}{c}-0.2165^{* * *} \\
(0.033)\end{array}$ & $\begin{array}{c}0.1073^{* * *} \\
(0.027)\end{array}$ & $\begin{array}{c}0.1468^{* * *} \\
(0.013)\end{array}$ & $\begin{array}{c}0.2125^{* * *} \\
(0.027)\end{array}$ & $\begin{array}{c}-0.2165^{* * *} \\
(0.029)\end{array}$ & $\begin{array}{c}0.1073^{* * *} \\
(0.032)\end{array}$ & $\begin{array}{c}0.1468^{* * *} \\
(0.023)\end{array}$ & $\begin{array}{c}0.2125^{* * *} \\
(0.053)\end{array}$ & $\begin{array}{c}-0.2165^{* * *} \\
(0.034)\end{array}$ \\
\hline Pc income growth & $\begin{array}{c}0.1957^{* * *} \\
(0.053)\end{array}$ & $\begin{array}{c}0.1912^{* * *} \\
(0.029)\end{array}$ & $\begin{array}{l}0.0314 \\
(0.078)\end{array}$ & $\begin{array}{l}-0.0009 \\
(0.058)\end{array}$ & $\begin{array}{c}0.1957^{* * *} \\
(0.063)\end{array}$ & $\begin{array}{c}0.1912^{* * *} \\
(0.036)\end{array}$ & $\begin{array}{l}0.0314 \\
(0.067)\end{array}$ & $\begin{array}{c}-0.0009 \\
(0.051)\end{array}$ & $\begin{array}{c}0.1957^{* * *} \\
(0.070)\end{array}$ & $\begin{array}{c}0.1912^{* * *} \\
(0.041)\end{array}$ & $\begin{array}{l}0.0314 \\
(0.090)\end{array}$ & $\begin{array}{l}-0.0009 \\
(0.066)\end{array}$ \\
\hline Population growth & $\begin{array}{c}0.6911^{* * *} \\
(0.173)\end{array}$ & $\begin{array}{c}0.7392^{* * *} \\
(0.089)\end{array}$ & $\begin{array}{c}1.8827^{* * * *} \\
(0.308)\end{array}$ & $\begin{array}{c}-1.0017^{* * *} \\
(0.210)\end{array}$ & $\begin{array}{c}0.6911^{* * *} \\
(0.247)\end{array}$ & $\begin{array}{c}0.7392^{* * *} \\
(0.064)\end{array}$ & $\begin{array}{c}1.8827^{* * *} \\
(0.273)\end{array}$ & $\begin{array}{c}-1.0017^{* * * *} \\
(0.189)\end{array}$ & $\begin{array}{c}0.6911^{* *} \\
(0.264)\end{array}$ & $\begin{array}{c}0.7392^{* * *} \\
(0.089)\end{array}$ & $\begin{array}{c}1.8827^{* * *} \\
(0.363)\end{array}$ & $\begin{array}{c}-1.0017^{* * *} \\
(0.245)\end{array}$ \\
\hline Firm sales growth & $\begin{array}{l}0.0117 \\
(0.010)\end{array}$ & $\begin{array}{c}0.0095^{* *} \\
(0.004)\end{array}$ & $\begin{array}{l}0.0054 \\
(0.006)\end{array}$ & $\begin{array}{l}0.0012 \\
(0.007)\end{array}$ & $\begin{array}{l}0.0117 \\
(0.008)\end{array}$ & $\begin{array}{c}0.0095^{* * *} \\
(0.003)\end{array}$ & $\begin{array}{l}0.0054 \\
(0.006)\end{array}$ & $\begin{array}{l}0.0012 \\
(0.007)\end{array}$ & $\begin{array}{l}0.0117 \\
(0.011)\end{array}$ & $\begin{array}{c}0.0095^{* *} \\
(0.004)\end{array}$ & $\begin{array}{l}0.0054 \\
(0.006)\end{array}$ & $\begin{array}{l}0.0012 \\
(0.008)\end{array}$ \\
\hline Bank size & $\begin{array}{c}-0.0129^{* * *} \\
(0.004)\end{array}$ & $\begin{array}{c}-0.0285^{* * *} \\
(0.003)\end{array}$ & $\begin{array}{c}-0.0096^{* * *} \\
(0.003)\end{array}$ & $\begin{array}{l}0.0009 \\
(0.004)\end{array}$ & $\begin{array}{c}-0.0129 * * * \\
(0.003)\end{array}$ & $\begin{array}{c}-0.0285^{* * *} \\
(0.001)\end{array}$ & $\begin{array}{c}-0.0096^{* * *} \\
(0.002)\end{array}$ & $\begin{array}{l}0.0009 \\
(0.003)\end{array}$ & $\begin{array}{c}-0.0129 * * * \\
(0.004)\end{array}$ & $\begin{array}{c}-0.0285^{* * *} \\
(0.003)\end{array}$ & $\begin{array}{c}-0.0096^{* * *} \\
(0.003)\end{array}$ & $\begin{array}{l}0.0009 \\
(0.005)\end{array}$ \\
\hline Bank capital & $\begin{array}{c}0.1170^{* * *} \\
(0.035)\end{array}$ & $\begin{array}{c}0.1588^{* * *} \\
(0.022)\end{array}$ & $\begin{array}{c}0.0714^{* *} \\
(0.026)\end{array}$ & $\begin{array}{c}-0.1035^{* * *} \\
(0.034)\end{array}$ & $\begin{array}{c}0.1170^{* * *} \\
(0.032)\end{array}$ & $\begin{array}{c}0.1588^{* * * *} \\
(0.022)\end{array}$ & $\begin{array}{c}0.0714^{* * *} \\
(0.026)\end{array}$ & $\begin{array}{c}-0.1035^{* * *} \\
(0.025)\end{array}$ & $\begin{array}{c}0.1170^{* * *} \\
(0.034)\end{array}$ & $\begin{array}{c}0.1588^{* * *} \\
(0.027)\end{array}$ & $\begin{array}{c}0.0714^{* *} \\
(0.030)\end{array}$ & $\begin{array}{c}-0.1035^{* * *} \\
(0.035)\end{array}$ \\
\hline Bank asset growth & $\begin{array}{c}0.6107^{* * *} \\
(0.013)\end{array}$ & & $\begin{array}{c}0.5803^{* * * *} \\
(0.019)\end{array}$ & $\begin{array}{c}0.9867^{* * *} \\
(0.019)\end{array}$ & $\begin{array}{c}0.6107^{* * *} \\
(0.014)\end{array}$ & & $\begin{array}{c}0.5803^{* * *} \\
(0.011)\end{array}$ & $\begin{array}{c}0.9867^{* * *} \\
(0.014)\end{array}$ & $\begin{array}{c}0.6107^{* * *} \\
(0.015)\end{array}$ & & $\begin{array}{c}0.5803^{* * *} \\
(0.020)\end{array}$ & $\begin{array}{c}0.9867^{* * * *} \\
(0.021)\end{array}$ \\
\hline Observations & 99,890 & 109,710 & 101,623 & 86,057 & 99,890 & 109,710 & 101,623 & 86,057 & 99,890 & 109,710 & 101,623 & 86,057 \\
\hline R-squared & 0.168 & 0.339 & 0.318 & 0.293 & 0.168 & 0.339 & 0.318 & 0.293 & 0.168 & 0.339 & 0.318 & 0.293 \\
\hline Year FE & Yes & Yes & Yes & Yes & Yes & Yes & Yes & Yes & Yes & Yes & Yes & Yes \\
\hline Bank FE & Yes & Yes & Yes & Yes & Yes & Yes & Yes & Yes & Yes & Yes & Yes & Yes \\
\hline
\end{tabular}

Notes: This table explores the robustness of the results to alternative clustering levels. The dependent variables are bank-level C\&I loan growth, total asset growth, real estate loan growth, and liquid asset growth. In columns 1-4 standard errors are double-clustered on bank and year; in columns 5-8 they are clustered on MSA; and in columns 9-12 they are double-clustered on MSA and year. The regressions are run in a bank-level panel over 1977-2010. \# indicates statistical significance at the $15 \%$ level, $* * *$ at the $1 \%$ level, ${ }^{* *}$ at the $5 \%$ level, and ${ }^{*}$ at the $10 \%$ level. 